Florida International University FIU Digital Commons

\title{
Progressive Saxonism: The Construction of Anglo- Saxonism in Jack London's The Valley of the Moon and Frank Norris's McTeague
}

Matthew John Soderblom

Florida International University, msode004@fiu.edu

DOI: $10.25148 /$ etd.FIDC001752

Follow this and additional works at: https:// digitalcommons.fiu.edu/etd

Part of the American Literature Commons, Cultural History Commons, Ethnic Studies Commons, and the Literature in English, North America Commons

\section{Recommended Citation}

Soderblom, Matthew John, "Progressive Saxonism: The Construction of Anglo-Saxonism in Jack London's The Valley of the Moon and Frank Norris's McTeague" (2017). FIU Electronic Theses and Dissertations. 3219.

https://digitalcommons.fiu.edu/etd/3219 


\section{FLORIDA INTERNATIONAL UNIVERSITY \\ Miami, Florida}

\section{PROGRESSIVE SAXONISM: THE CONSTRUCTION OF ANGLO-SAXONISM IN JACK LONDON'S THE VALLEY OF THE MOON AND FRANK NORRIS'S MCTEAGUE}

A thesis submitted in partial fulfillment of the requirements for the degree of MASTER OF ARTS

in

ENGLISH

by

Matthew John Soderblom 
To: Dean Michael R. Heithaus

College of Arts, Sciences and Education

This thesis, written by Matthew John Soderblom, and entitled Progressive Saxonism: The Construction of Anglo-Saxonism in Jack London's The Valley of the Moon and Frank Norris's McTeague, having been approved in respect to style and intellectual content, is referred to you for judgment.

We have read this thesis and recommend that it be approved.

$\begin{array}{r}\hline \text { Nandini Dhar } \\ \hline \text { Martha Schoolman } \\ \hline \text { Nathaniel Cadle, Major Professor }\end{array}$

Date of Defense: March 31, 2017

The Thesis of Matthew John Soderblom is approved.

Dean Michael R. Heithaus

College of Arts, Sciences and Education

Andrés G. Gil

Vice President for Research and Economic Development and Dean of the University Graduate School

Florida International University, 2017 


\section{DEDICATION}

I dedicate this thesis to my mother who always encouraged me in all of my intellectual pursuits and taught me to never quit.

Also, this is for my father who taught me that educating others is an art form.

Finally, this is dedicated to my girlfriend, Niamh Farrell, who helped me every step of the way. 


\section{ACKNOWLEDGMENTS}

I would like to thank Dr. Nathaniel Cadle, Dr. Nandini Dhar, and Dr. Martha Schoolman for broadening my literary horizons.

Also, I would like to extend my gratitude towards Florida International University. I am eternally grateful for my time as a teaching assistant. This University has fostered an undying love for educating others.

As a child, I found racial identity to be a peculiar, puzzling aspect of life. My relatives prized my Swedish surname and Mediterranean features. Yet, my parents were of Italian, English, Swedish, and German extraction. These were the four identifiable nationalities that I felt connected to. However, these four ancestral homelands simplified my heritage. There are a myriad of other nations that comprise my being. In my youth, I was often told that I was “just white." This designation was accepted as a universal truth. First, I was white. Second, I was European. As the years rolled on, I constructed my identity as much as society did. I romanticized my ancestors. The Englishmen were Kentish shipwrights who later became privateers. The Germans fought in the FrancoPrussian war. My Swedish ancestors must have been seafaring Vikings. The Italians were once Romans who repelled Carthaginian invaders. The veracity of these claims has never been fully substantiated, and yet I was keen to accept them as factual. I relied upon these legends to construct my personal identity. However, as a young man, I was unaware of the unjust policies and legislation that were largely the result of the construction of whiteness. This ancient idea began eons ago. My current project seeks to confront these hateful ideas in an attempt to better understand the history of the United States, the way in which fiction reflected reality, and to acknowledge my own white privilege. 


\begin{abstract}
OF THE THESIS
PROGRESSIVE SAXONISM: THE CONSTRUCTION OF ANGLO-SAXONISM IN

JACK LONDON'S THE VALLEY OF THE MOON

AND FRANK NORRIS'S MCTEAGUE
\end{abstract}

by

Matthew John Soderblom

Florida International University, 2017

Miami, Florida

Professor Nathaniel Cadle, Major Professor

The purpose of my thesis seeks to uncover the constructed nature of the AngloSaxon ethnicity within two works of fiction. My thesis utilizes London's The Valley of the Moon (1913) and Norris's McTeague (1899) because they were published in a similar era. Both authors lived and wrote in the Bay Area during the Progressive Era of American politics. Therefore, there is political, stylistic, and regional proximity. Although Anglo-Saxonism has always been present in the United States, the construction of race was changing in the 1900s. The Valley of the Moon and McTeague both contain intriguing (and antiquated) notions of whiteness that further exacerbate the class struggle in California. This thesis describes the convergence of Progressive politics, eugenics, and Marxism within a unique chapter of American history. Through an exploration of AngloSaxonism, this examination of racial classifications is an attempt to reveal the inner workings of oppression in America. 


\section{TABLE OF CONTENTS}

CHAPTER

PAGE

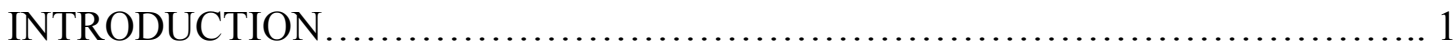

CHAPTER I: RACE AND LABOR IN NORRIS'S MCTEAGUE.............................12

CHAPTER II: WHITENESS IN LONDON'S THE VALLEY OF THE MOON......39

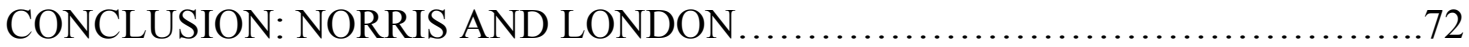

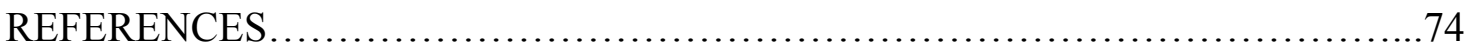




\section{INTRODUCTION}

Jack London's The Valley of the Moon (1913) and Frank Norris's McTeague (1899) employ some of the vilest rhetoric about race within American literature. While these two writers were indeed masters of their craft, the inflammatory nature of their racial categorizations had counterparts in American political thought. In many ways, these two novels employ the rhetorical techniques of the Progressives and the research of eugenicists. Norris and London both depict a bleak economic reality for the whites of San Francisco and Oakland. Urbanization leads to housing crises and a glut of supposedly threatening immigrants. In this respect, the urban space is not advantageous for the advancement of the Anglo-Saxons. Close proximity to races deemed inferior poses a threat to Anglo-Saxon genetics and employment. Norris and London's idealized working class is slowly being displaced by a horde of immigrants.

Both writers emphasize the gritty nature of urban life. Norris's San Francisco and London's Oakland are violent, dirty, morally decrepit, and overpopulated. In constructing these narratives, Norris and London allow their readers to observe early twentieth-century men and women in their supposedly "natural" habitats. In both cases, however, the urban landscape is an unsuitable habitat for any member of humanity. Norris and London both utilize a Marxist understanding of labor to emphasize the exploitation of Anglo-Saxon workers. While members of all ethnic groups are being taken advantage of by the upper classes, London's The Valley of the Moon romanticizes the struggle of a single AngloSaxon couple. On the other hand, the characters in McTeague are either unaware of their exact ethnic origins or are descended from a non-Anglo-Saxon immigrant group. Norris's version of the San Francisco landscape epitomizes Josiah Strong's influential 
Progressivist idea that urban centers are cesspools in need of Anglo-Saxon leadership or intervention. My focus on these two novels highlights the prioritizing of Anglo-Saxons despite the diversity already present within Norris and London's California. At the heart of my thesis is the exploration of early twentieth-century American Anglo-Saxonism, within two novels, to reveals its constructed, arbitrary nature.

My project relies on a wide-ranging set of ideas promoted by various scholars. For the sections concerned with economics, the work of Marx, Engels, and Althusser present vital ideas concerning the structures within capitalistic societies and how these structures are always-already present in reality and in fiction. Marx and Engel's ideas of wages and labor-power are indispensable in examining the economies of Norris and London's novels. My study also builds on the work of Michel Foucault, who (along with Louis Althusser) presents great truths about the repressive actions of governmental institutions and their effects on the lives of individuals. In terms of Norris and London's novels, these ideas of administrative oppression are seen in the struggles of the AngloSaxon contingent of the working class.

Coupled with ideas of class anxiety, my thesis also uses two influential texts on Whiteness studies to complicate London and Norris's depictions of race. The first book, Reginald Horsman's Race and Manifest Destiny, offers an explanation of AngloSaxonism in the first half of the nineteenth century. In an excerpt from the book (which also appeared in Richard Delgado and Jean Stefancic's collection, Critical White Studies: Looking Behind the Mirror), Horsman succinctly summarizes nineteenth-century AngloSaxonism: "By 1850 American expansion was viewed in the United States less as a victory for the principles of free democratic republicanism than as evidence of the innate 
superiority of the American Anglo-Saxon branch of the Caucasian race" (rpt. in Delgado 141). There is an assertion here that the Anglo-Saxon identity was beginning to take shape in American society. The shift from pride in free democratic republicanism toward Anglo-Saxonism represents a constructed racial category that enables the ethnocentrism of Norris and London's novels.

Pairing Horsman's history of Anglo-Saxonism with Noel Ignatiev's How the Irish Became White allows for a more nuanced discussion of London and Norris's novels. Ignatiev's focus on Celtic immigration to the United States and their similarities and differences to the country's African American population helps to track the development and expansion of whiteness within the country. In the context of Norris and London's novels, the Irish are on the cusp of widespread acceptance. No longer shown quite as much disdain as immigrants and other minorities, Irish-Americans' skin color allows them to become second to the Anglo-Saxons. In a reference to the 1852 Longshoremen's United Benevolent Society, Ignatiev writes that the association's banner included the flags of various European nations (France, Germany, Denmark, Ireland, Sweden, etc.). Its design was to promote solidarity among the longshoremen, Ignatiev writes: "These Irish showed they had learned well the lesson that they would make their way in the U.S not as Irishmen but as whites" (Ignatiev 121). Lacking the supposedly Germanic blood and Protestantism of their Anglo-Saxon counterparts, the Irish slowly ascended the American social ladder.

The characters in McTeague and The Valley of the Moon are also participants in class struggle. Marxian ideas are employed in both novels to highlight the chaos of an urban landscape. In McTeague, the dull dentist lives in direct competition with other 
dentists in his area. His signpost acts as his greatest means for attracting clients. However, his dental office (in the early parts of the book) doubles as his domicile. The economic structures in place maintain McTeague's state of relative indigence. The dentist's socio-economic status is altered by his marriage to Trina Sieppe. With access to her lottery winnings, it appears that McTeague will gain greater status in San Francisco's society. Unfortunately, this upward mobility results in McTeague being subjected to greater institutional controls.

While McTeague struggles with upward mobility, the characters in The Valley of the Moon also face similar issues. London's male protagonist, Billy Turner, actively participates in Teamster strikes in Oakland. For a lengthy period of time, the city erupts in violent skirmishes between the strikers and strikebreakers. Throughout this section of the novel, Billy sustains dreadful injuries and is eventually imprisoned. Socialist agitators, union leaders, and business owners are omnipresent and they fan the flames of civil unrest. Unlike those around them, Billy and Saxon (his wife) do not find solace in socialist ideals. Instead, they rely on the construct that their Anglo-Saxon genes will allow them to carve out their own stake in American society. For both novels, the figure of the Anglo-Saxon is a stabilizing presence in uncertain economic situations, while race has an inherent value that determines whether or not a person has the capability of success.

Concerning the constructed nature of race, Edward Said's idea of the other is essential to understanding London and Norris's novels. Both authors create characters whose identities rely on the people around them. For example, in The Valley of the Moon, Anglo-Saxon characters distinguish themselves from others by asserting that their 
ancestors arrived at an earlier time in the development of the United States. Moreover, McTeague's characters possess inherent traits that are the result of an essential and monolithic "German-ness," "Irish-ness," etc. These fundamental traits are then used to explain many of their behaviors. The act of othering is a key component of the pervasive belief in Anglo-Saxonism of the period. Therefore, the Anglo-Saxons cannot assert supremacy without differentiating themselves from ethnicities deemed beneath them.

When discussing McTeague, many critics note that the novel exemplifies the oppressive racial hierarchy of the turn-of-the-twentieth century United States. In her essay, "The Nature of the Beast: Scientific Theories of Race and Sexuality in McTeague," Rebecca Nisetech elaborates on the intricacies of the pseudo-scientific racial classifications in the novel. Although she breaks down the various stereotypes present in the novel, her conclusion is limited: "Norris certainly exploits white American cultural fears of over-civilization and over-exposure to the degenerative stimuli of gratuitous violence and sexual perversion, repelling and intriguing readers at once. But he also assures them that they, the favored race, have nothing to fear from the progressive unfolding of their destiny" (Nisetech 19). In identifying the race science present in the novel, Nisetech's assertions are quite accurate. However, for the purposes of this project, Nisetech's ideas miss the mark on McTeague. In the final scene where McTeague is handcuffed to Marcus's body, the stakes are much higher for Norris's Anglo-Saxon audience than Nisetech acknowledges. Norris preys upon the anxiety of his Anglo-Saxon readers. Characters such as McTeague, Marcus, Trina, Maria Macapa, and Zerkow compose the city of San Francisco. Due to its environment, it is inevitable that McTeague will die in the inhospitable climate of Death Valley. Yet, these supposed lesser ethnicities 
are being allowed to breed without consequence in American urban centers. For Josiah Strong and various members of the Progressive movement, it was an Anglo-Saxon's duty to civilize and Christianize their alleged subordinates. Norris capitalizes on his audiences' anxieties and Strong's ideas to further assert that society will wither without AngloSaxon leadership.

After establishing the critical and historical context, the first chapter of this project is dedicated to the economic and racial underpinnings of Frank Norris's McTeague. The first section of the chapter begins with a discussion of Donald Pizer's classification of Norris's naturalism. Norris detests the niceties of nineteenth-century realist writing and borrows heavily from Emile Zola's brutal prose. A focus on the "primitive" better enables Norris to depict the struggles of his Bay Area characters. Norris's work captures a human affinity for greed and vice. Underscoring the connections between literature and its sociopolitical context, Norris's fiction finds its real-world equivalent in Josiah Strong's Progressive Era writings on the Social Gospel movement.

As previously stated, Josiah Strong wrote extensively on the topic of an AngloSaxon's duty to America. Strong believed that cities were the swamplands of human existence. Every vice and immoral action occurred within their confines. Strong was concerned with the alcoholism, decadence, miscegenation, addiction, poverty, mental illness, inequality, violence, and dilution of Anglo-Saxon genetics within cities. Yet, Strong claimed that American society was not without hope. He argued that AngloSaxons were responsible for the perfection of human society. In his most famous work, Our Country (1885), Strong dramatically highlights these duties: "We of this generation and nation occupy the Gibraltar of the ages which commands the world's future" (Strong 
180). He uses this poetic declaration to argue for the Anglo-Saxon's so-called superiority. In this manner, Strong perverts Christian doctrines as a way of boosting Anglo-Saxon self-esteem. The Social Gospeller-in-chief provides ample subtext for Norris's McTeague.

Paired with the writings of Strong, the ideas of English eugenicist, Francis Galton, play a vital role in McTeague. As Nisetech points out in "The Nature of the Beast," Out of this milieu grew the field of eugenics. Defined by Francis Galton in his 1883 Inquiries into the Human Faculty and Its Development as "the science of improving [racial] stock" (qtd. in Somerville, "Scientific Racism" 30), eugenics essentially applied Darwin's deterministic theory of natural selection to the artificial selection of human beings. (Nisetech 2)

Galton's ideas pervade McTeague. The bumbling dentist is born with lesser intellectual traits. His only advantage over his contemporaries is his innate, terrible strength. Norris emphasizes that this attribute is superhuman and enables McTeague to perform dental surgery without implements and other physical feats (strangling Trina and Marcus to death, for example). Yet, McTeague is prone to alcohol abuse and severely lacks intelligence. Norris's dentist is an unintelligent and relatively good-natured brute who becomes a victim of society.

Walter Benn Michaels' ideas of Nativism inform my chapter on Norris's novel as well. Within McTeague, what Michaels, in his book Our America, calls "Nativist Modernism" develops over the course of the narrative. Norris's novel depicts a brutal San Francisco where many races compete for scarce resources and miscegenation is ubiquitous. Norris's McTeague does not welcome the changing times (McTeague's need 
for a medical license to ply his trade, for example). This negative portrayal of other ethnicities and the bureaucratic restrictions on practicing dentistry are two ways in which this novel rejects modernity. As in Josiah Strong's nonfiction, McTeague suggests that the Anglo-Saxon must not become a victim of modernity. There is a constant anxiety in the novel that these supposedly inferior members of various ethnicities (and the working classes) are the slippery slope that will lead to the ruin of all human progress.

The first chapter will conclude with an exploration of McTeague's contemporaries and the ways in which race, vice, and greed play roles in each character's demise. Trina Sieppe and Marcus Schouler's Germanic origins will be thoroughly explored and compared to Zerkow and Maria's self-serving qualities. Both Polish and Jewish, Zerkow is perhaps Norris's most insultingly portrayed character in the novel. The Pole is indigent, ruthless, greedy, and irrational. This unfortunate description also extends to Maria Macapa, Zerkow's Mexican wife. Norris utilizes these characters' ethnicity as shorthand to explain all of their behaviors. However, their inclinations toward greed and vice are not solely determined by race. Environmental factors play a large role in characterizing these four. Again echoing Strong's ideas about cities, Norris's depiction of San Francisco is a guide for his Anglo-Saxon readers. McTeague is a primer for the Anglo-Saxon in that it catalogues the tendencies of the so-called inferior ethnicities. In the second chapter of this project, I expand my exploration of Progressive Era political thought and the work of race scientists through a reading of Jack London's The Valley of the Moon. Thomas Leonard's Illiberal Reformers: Race, Eugenics, and American Economics in the Progressive Era, a recent overview of economics and ideas of race in the late nineteenth and early twentieth centuries, provides important context for 
understanding this novel. The Valley of the Moon employs logic that was common to Josiah Strong, President Woodrow Wilson, William Z. Ripley, and other Progressives of this era. The Valley of the Moon also affirms and amplifies the fears displayed in McTeague. Throughout London's novel, there is great anxiety about the lack of a place for members of the Anglo-Saxon working class in American society.

The second chapter also responds to Christopher Gair's“"The Way Our People Came: Citizenship, Capitalism, and Racial Difference in The Valley of the Moon" in order to establish the idea that Billy and Saxon Roberts are two Anglo-Saxons coming to terms with the changing times. The two protagonists display an ingenuity that London believes is innate in Anglo-Saxons. As such, there is a shift in space from urban to rural. Gair focuses on the alleged Anglo-Saxon superiority. Billy and Saxon believe that their connection to the early settlers of the United States gives them a sense of ownership and authenticity. In Gair's view, Saxon and Billy's reversion to subsistence farming represents a great weakness in The Valley of the Moon. Thus, London's vulnerability is rooted in the belief that these ideas of Anglo-Saxonism are not strong enough to oppose the iniquities of a capitalistic society.

While Gair's argument is convincing to a point, my study concerns itself with the ways in which London's characters are to preserve Anglo-Saxon hegemony. London's racial classifications and descriptions of socio-economic affairs are in no way revolutionary. By explicating The Valley of the Moon through Progressive thought, Said's rhetoric, and race science, I argue that London's characters, at the end of the novel, are quite content with maintaining the status quo. The struggle for the greater good of the Anglo-Saxon is only partially Saxon and Billy's intent. In establishing a successful 
farming business, the two characters are examples of an Anglo-Saxon success story. Instead of London's usual setting in the wilderness, the pair survives the wilds of Oakland. Saxon and Billy are used as evidence to support the idea that the Anglo-Saxon can reclaim his or her "rightful" heritage.

With ideas reminiscent of Josiah Strong, London utilizes Saxon and Billy to explore alternatives for urban-dwelling Anglo-Saxons. The duo travels throughout California in search of a place to call home. Along the way, London's descriptions of other ethnicities echo many of the American economist William Z. Ripley's influential ideas about race, which Ripley began expounding in the 1890s. Ripley's terminology of the Teutonic, Alpine, and Mediterranean races is not overtly adopted by London; however, these ideas are implicit in London's descriptions of the Irish and Southern and Eastern European immigrants. The Valley of the Moon is rife with stereotypical portrayals of many ethnicities. In exploring these descriptions, together with Progressive beliefs, the scope of The Valley of the Moon is widened. It becomes more than a reactionary novel that expresses disillusionment with issues of immigration and economic inequalities.

Ethnicity and socio-economic inequality are key factors in exploring these two novels. My project uses the arguments of turn-of-the-twentieth-century economic theorists, Progressive intellectuals, and pseudo-scientists to situate each novel. The Valley of the Moon and McTeague are very much products of the political, religious, "scientific," and economic thought of their era. Through their characters, Norris and London display a heavy anxiety about the place of the Anglo-Saxon in American society. It is my intention to show that fiction is often shaped by environmental factors (political, religious, and scientific thought) of its era. While fictional, these two works describe very 
real anxieties held by Anglo-Saxon members of society. In this manner, fiction and politics reinforce one another to maintain a reality that is governed by oppressive systems. 


\section{CHAPTER I: RACE AND LABOR IN NORRIS'S McTEAGUE}

A compelling tale of the working classes in nineteenth-century San Francisco, Frank Norris's McTeague (1899) explores the modernization of various professions and the interactions of multiple ethnicities in urban society. Norris's depiction of San Francisco touches upon how city life causes the degeneration of human society. Many of the issues covered in McTeague (alcoholism, miscegenation, and government intervention) were the focus of U.S. politics of the late nineteenth and early twentieth centuries. The cruel San Francisco of Norris's novel is rife with indulgence, sloth, moral decay, greed, and social inequality. For many of Norris's readers, McTeague is an ominous novel that exemplifies the moral bankruptcy of modern society.

As a writer in the naturalist school, Norris sought to describe the iniquitous sides of human nature. Donald Pizer explains Norris's idea of naturalism this way:

Norris's conception of naturalism is nevertheless significant both for what it contains and what it omits. Naturalism, Norris declares, must abjure the "teacup tragedies" of Howellsian realism and explore instead the irrational and primitive in human nature - "the unplumbed depths of the human heart, and the mystery of sex, and the problems of life, and the black, unsearched penetralia of the soul of man" - and it should do so within the large canvas and allegorical framework that permit the expression of abstract ideas about the human condition. (Pizer 104)

According to Pizer's logic, Norris wanted to capture the grittiness of urban environments. Norris's San Francisco is filled with idleness, decadence, poverty, indulgence, and class tensions. All of these aspects better adhere to the traditions of naturalism rather than realism. Pizer's description provides insight into Norris's writing objectives. For Norris, 
Howellsian realism inhibits effective writing. William Dean Howells' novels are too tame to capture the whole catalogue of human emotions.

This gritty depiction of the desperate conditions within an urban center also gained a foothold in the political and social writings of the late nineteenth century. As noted in the introduction, Norris's McTeague echoes the theme of moral decrepitude within urban centers that structured Josiah Strong's influential 1885 book Our Country. McTeague, the eponymous protagonist, frequently consumes alcohol, is extremely lacking in intelligence, possesses only brute strength, and lives in a community filled with racial others. For Josiah Strong, Frank Norris, and their contemporaries, the atmosphere of McTeague is all too familiar. In an excerpt from Strong's invective on society, alcohol and immigration are two subjects (amongst many others) of his vitriol. Strong writes:

We can only glance at the political aspects of immigration. As we have already seen, it is immigration which has fed fat the liquor power; and there is a liquor vote. Immigration furnishes most of the victims of Mormonism; and there is a Mormon vote. Immigration is the strength of the Catholic Church; and there is a Catholic vote. Immigration is the mother and nurse of American socialism; and there is to be a socialist vote. Immigration tends strongly to the cities, and gives to them their political complexion. And there is no more serious menace to our civilization than our rabble-ruled cities. These several perils, all of which are enhanced by immigration, will be considered in succeeding chapters. (Strong 43) Here, Strong utilizes faulty logic to argue that the fate of the United States is endangered by immigrants' wanton disregard for the welfare of the nation. For Strong, American 
cities were cesspools of human society. To preserve America, the upper echelons of society, namely Americans with Anglo-Saxon blood, were morally accountable for ensuring the prosperity of the country.

Norris's painstaking attention to detail captures the entire breadth of McTeague's social status. McTeague's ethnicity, surname, and habits are the antithesis of Josiah Strong's ideal Anglo-Saxon. Norris describes the Celtic-blooded protagonist's few worldly pleasures: "to eat, to smoke, to sleep, and to play upon his concertina" (Norris 1). Norris classifies McTeague as one of society's urchins. Despite his adequately successful business, McTeague is indolent and unintelligent. Lacking great intellect, McTeague is nevertheless relatively capable on the rare occasion where he conducts business. Norris's protagonist is gifted with great brute strength, which has its value. However, McTeague is better suited for manual labor. While many are employed in factories, McTeague is fortunate enough to own his own business. Strong advocated for the Anglo-Saxons and the protestant work ethic, and Norris's McTeague works by demonstrating all the aspects of urban life that Strong sought to expose.

Josiah Strong's Anglo-Saxonism manifests itself negatively within Norris's novel. First, McTeague is a simpleminded man of Celtic origin. Only utilizing a surname, Norris emphasizes the Celtic otherness of his protagonist. The origins of the "McTeague" name are rooted in Ireland and Scotland (two of the six "Celtic nations"). The prefix Mac and $M c$ in Gaelic (Scottish Gaelic and Irish, respectively) denote that one is the son of another (usually applied to a profession or craftsmen). According to the Oxford English Dictionary, the latter half of McTeague's name is derived from Tadhg, which is Gaelic for "poet" or "storyteller." His surname suggests that he is descended from one with 
literary merit. Perhaps, this suggests that his penchant for playing the concertina is a hereditary trait. Therefore, in Norris's nineteenth century logic, McTeague's indolence could be explained by his genetics.

With ambiguous Scots-Irish origins, McTeague also suggests the apparent inferiority of those with Celtic blood. As an ambiguous ethnicity, the Scots-Irish are a mixture of Northern Irish and Scottish stock. There is also the possibility that McTeague may be descended from Irish Roman Catholics. Long the targets of criticism and nativism, the Irish were often reminded that they are not of Anglo-Saxon blood. In How the Irish Became White, Noel Ignatiev writes of the antebellum-era perception of the Irish: "Strong tendencies existed in antebellum America to consign the Irish, if not to the black race, then to an intermediate race located socially between black and white" (Ignatiev 76). Not quite equal to the Anglo-Saxons, Ignatiev points out that the complexion of the Irish provided eligibility to join the white race. Over time, many Americans abandoned notions of nativism, but the Irish remained racial others. Norris's depiction of McTeague aligns with the antebellum perception of the Irish are McTeague's lack of intellect, fondness for alcohol, physical strength, and loyalty to the Roman Catholic Church are all stereotypes associated with the Irish. Josiah Strong's invectives utilized the Irish (and other ethnic groups) to reinforce the notion of Anglo-Saxon supremacy.

\section{Eugenics, Nativism, and McTeague's Ethnicity}

In the seminal Our America, Walter Benn Michaels argues for the exploration of modernism alongside nativism. He writes, "Both nativism and modernism will be present 
as efforts to work out the meaning of the commitment to identity-linguistic, national, cultural, racial - that I will argue is common to both" (Michaels 3). Drawing on Michaels' idea, my argument seeks to extend this exploration of nativism to nineteenth and twentieth-century naturalism. The linguistic, national, cultural, and racial characteristics of modernism are evident within Norris's naturalism, which Michaels somewhat surprisingly fails to acknowledge.

McTeague's background indicates that he rises from poverty to become relatively successful. The following description of McTeague epitomizes Strong's concerns about immigrant families. Sitting alone in his office, which doubles as a home, McTeague reminisces about his upbringing that underscores the harsh San Franciscan environment: "McTeague remembered his mother, too, who, with the help of the Chinaman, cooked for forty miners. She was an overworked drudge, fiery and energetic for all that, filled with the one idea of having her son rise in life and enter a profession. The chance had come at last when the father died, corroded with alcohol, collapsing in a few hours" (Norris 2). As a child, McTeague's parents worked in the mining industry. Norris utilizes this backdrop to emphasize both McTeague's humble origins and the undesirable conditions of the late nineteenth-century urban world and the ethnic minorities who inhabited it. From infancy, McTeague is financially and genetically disadvantaged.

Norris continues this description by chronicling McTeague's vocational training in the dental profession. Despite her occupation as a cook, McTeague's mother recognized an opportunity for her son to make a living for himself. Shortly after McTeague's father succumbed to alcoholism, a dentist visited the mining camp. Norris juxtaposes tragedy with opportunity to show the natural progression of life: 
Two or three years later a travelling dentist visited the mine and put up his tent near the bunk-house. He was more or less of a charlatan, but he fired Mrs. McTeague's ambition, and young McTeague went away with him to learn his profession. He had learnt it after a fashion, mostly by watching the charlatan operate. He had read many of the necessary books, but he was too hopelessly stupid to get much benefit from them. (Norris 2)

Another poor role model for young McTeague appears. The fact that his biological father is an alcoholic and his other male role model is a "charlatan" dentist illustrates how genetic and environmental factors will shape McTeague's development. Thus, McTeague inherits his alcoholism from his father and learns how to behave from his mentor. Referring to McTeague's father, Norris writes, "Every other Sunday he became an irresponsible animal, a beast, a brute, crazy with alcohol" (Norris 2). However, Norris also emphasizes McTeague's learning style. Instead of utilizing books, the fledgling dentist imitates what he sees. For Norris, McTeague's response to visual stimuli rather than a textbook is evidence of the protagonist's inherent feeblemindedness.

The "nature versus nurture" debate factors into Norris's characterization of McTeague. Francis Galton, an English Progressive and pioneering eugenicist who argued that hereditary and environmental factors are at odds with one another, coined that phrase. The first sentence of Galton's Hereditary Genius contains the crux of his argument: "I propose to show in this book that a man's natural abilities are derived by inheritance, under exactly the same limitations as are the form and physical features of the organic world" (Galton 1). Here, Galton states that humankind's natural abilities are 
primarily innate. His seemingly benign argument does not yet betray the racist elements of his treatise.

If one were to read McTeague in light of Galton's research, Norris's slow-witted dentist neither inherits positive intellectual traits nor does he adapt well to his environment. Rather, McTeague only inherits the physical strength of his parents. He is the product of low breeding and is doomed to repeat the mistakes of his ancestors. Aside from simply inheriting his dull wits, McTeague lacks good genes, which also factors into his ethnic identity. Galton's belief in the supremacy of inherited genes prioritized the Anglo-Saxon. The eugenicist asserted that Anglo-Saxons attained supremacy due to the inherent superiority of their genetics. McTeague fits neither Galton's nor Strong's idealized portrait of an Anglo-Saxon. Rather, Norris's depiction of McTeague exemplifies Galton's negative ideas on race. The Celtic dentist is condemned by both his impoverished genetics and his inability to adapt to his surroundings.

Aside from genetic factors and surname, appearance also plays a role in the McTeague's Celtic identity. Physically, McTeague is an impressive specimen. Norris describes McTeague as "a young giant, carrying his huge shock of blond hair six feet three inches from the ground; moving his immense limbs, heavy with ropes of muscle, slowly, ponderously" (Norris 2). Similar in appearance to the idealized Anglo-Saxons of old, the resemblance ends there. The positively Celtic surname and disposition signal McTeague's supposed racial deficiencies. His appearance and surname are similar to Galton's conclusions about the Scottish: "The Scotch are by no means a strictly uniform race, nor are they exposed to identical conditions. They are a mixture of Celts, Danes, Anglo-Saxons, and others, in various proportions" (Galton 26). Although McTeague and 
the Scotsmen of Galton's study resemble the Anglo-Saxon, there is a marked difference in their behaviors. Scotsmen and McTeague possess less Germanic blood than Englishmen (and their American descendants). For Galton and Norris, appearances are deceptive. They center their beliefs on the idea that a man's pedigree determines his place in the world.

\section{The Value of Labor and its Class Implications}

Ethnic conflicts in McTeague run parallel to class tensions. Norris's depiction of San Francisco underlines the disparity between the upper and lower classes. On McTeague's street, Norris describes a vast array of laborers on their way to work:

This little army of workers, tramping steadily in one direction, met and mingled with other toilers of a different description--conductors and "swing men" of the cable company going on duty; heavy-eyed night clerks from the drug stores on their way home to sleep; roundsmen returning to the precinct police station to make their night report, and Chinese market gardeners teetering past under their heavy baskets. The cable cars began to fill up; all along the street could be seen the shopkeepers taking down their shutters. (Norris 4)

Aside from the obvious racialization of the Chinese laborers, one might assume that these laborers are all of white European descent. Throughout the novel, physical laborers are the unheralded pillars of society. McTeague's lack of intellect and awareness allows Norris to focus on the smaller cogs in the machine. These working-class laborers highlight the physical side of labor. Yet, as a dentist, McTeague's social position is not quite superior to these men. 
McTeague's occupation does not require the backbreaking labor of a factory worker or pipefitter. Rather, McTeague's dental practice allows him a relative level of solitude and respite. Pipefitters, gardeners, and factory workers are unable to set the conditions that they work in. Yet, McTeague relies on a similar skillset to perform uncomplicated procedures. McTeague's brute strength is more important than any of his dental implements. Bankrupt in wits, physical strength is the one positive trait of Norris's protagonist.

Outside of his office, McTeague's sign reads, “"Doctor McTeague. Dental Parlors. Gas given'” (McTeague 3). The signpost's sparse description details all of the services that McTeague can provide and it also displays his limited qualifications. Although, its simplicity serves as a marker of the dentist's class. He is not quite a wealthy man. However, his signboard looms over the menial job-holding pedestrians. By hanging over passersby, McTeague's marquee figuratively demonstrates his slightly higher status in society. Large factory owners, the city, or various other entrepreneurs employ these other workers. McTeague's business allows him a degree of freedom unavailable to his fellow San Franciscans. Therefore, McTeague sets his own hours and a rather low demand for his services generates lengthy periods of rest. Despite the fact that his home and office occupy the same space, McTeague's living and working conditions are within his control.

Karl Marx’s essay “Wages, Labour, and Capital,” further contextualizes McTeague's living conditions. While Marx aptly describes the labor of a factory worker as one who "receive[s] means of subsistence in exchange for his labor-power" (Marx 31), this idea is also applicable to the oafish dentist. Neither McTeague nor the factory 
workers have ownership of the tangible objects they create. Rather, they are merely paid for their time to perform specific actions. McTeague's living conditions are not entirely dissimilar to the factory workers'. Before McTeague's marriage to Trina and their brief period of marital and financial bliss, he subsists on wages that are slightly better than those of his contemporaries. Working six days a week, McTeague spends his Sundays in an intoxicated state. Where the factory workers must work a designated number of hours, McTeague's wages are determined by the price of his supplies, the time it takes to complete an operation, the amount of completed operations, and the type of dental procedure performed.

The conditions of McTeague's work environment also allow him to meet his future wife and shed light upon the struggle for steady work in San Francisco. Marcus Schouler, McTeague's best companion and later greatest adversary, introduces the dentist to Trina Sieppe. After an accident, Marcus's cousin Trina has lost a tooth. Marcus informs McTeague that Trina will visit his office the next day. New clients are a dentist's only means of expanding his business. Thus, McTeague relies on his current clients to continue his dental enterprise. Word of mouth and his signboard are his sole means of advertising. As a member of the less affluent classes, McTeague does not have the resources of the more reputable dentists of the city (to whom he is later forced to sell his dental equipment). However, McTeague's savage strength allows him to perform procedures with his bare hands. Marcus describes McTeague's brutishness: "Say, Trina, he's the strongest duck you ever saw. What do you suppose? He can pull out your teeth with his fingers; yes he can" (Norris 12). In this sequence of events, Norris uses Marcus's statement to show the natural strength of McTeague as well as the class of all of these 
characters. Presumably, members of the upper classes were not visiting dentists who relied on finger strength as opposed to appropriate dental implements.

McTeague's success as a dentist is relatively brief. Upon meeting Trina, McTeague is smitten with her. Norris states that the "male virile desire in him tardily awakened, aroused itself, strong and brutal. It was resistless, untrained, a thing not to be held in leash an instant" (Norris 16). The appointment with Trina evokes the sexual urges of McTeague. However, this relationship is forever rooted in the exchange of capital. Desiring a medical service, Trina must provide the appropriate amount of currency for McTeague to render his services. In lieu of currency, McTeague's animalistic nature yearns for Trina herself.

After approximately a week of providing dental care to Trina, McTeague feels the pull of the brute within. Watching Trina as she succumbs to the effects of ether, McTeague faces a dilemma. Norris describes the scene: "For some time he stood watching her as she lay there, unconscious and helpless, and very pretty. He was alone with her and she was absolutely without defense" (Norris 18). McTeague's desire for Trina awakens when she is in a vulnerable state. For the lustful dentist, an incapacitated Trina represents a different variety of exchange.

Trina's vulnerable state serves as the catalyst to McTeague's professional life. Prior to this point, dentistry has always served as a means of putting food on the table. Trina presents a new form of temptation. She is a new material that he can acquire. With Trina still under the ether's spell, McTeague consciously tries to suppress his desire. Yet, McTeague begins to succumb to his sexual urges: "Suddenly he leaned over and kissed her, grossly, fully on the mouth. The thing was done before he knew it. Terrified at his 
weakness at the very moment he believed himself strong, he threw himself once more into his work with desperate energy" (Norris 18-9). Norris demonstrates the struggle within McTeague. The animalistic nature confronts the rational side and is briefly victorious. McTeague almost forces himself upon the helpless young lady, until his dim mind finds another means of exchange.

After kissing an unconscious Trina, the procedure continues without further incident. Norris writes, "McTeague went on with his work. As he was rapping in the little blocks and cylinders with the mallet, Trina slowly came back to herself with a long sigh... By and by she said, 'I never felt a thing' and then she smiled at him very prettily beneath the rubber dam" (Norris 19). Following McTeague's lapse in judgment, Norris highlights Trina's innocence. Trina recovers from the effects of ether unaware that McTeague harbors thoughts of violating her. The bumbling protagonist's unromantic kiss borders on sexual assault. Yet, this is an example of man almost yielding to Norris's idea of natural behavior. McTeague's moral training thwarts this potential sexual assault. However, labor is the other component that halts his behavior. Trina's money is more essential to McTeague's survival. Although McTeague is afforded some degree of pleasure, at some level he is aware that assaulting one's clients is not a sound business practice. Therefore, the economic pitfalls outweigh the risk of violating a patient.

After awakening Trina, McTeague's desire for Trina continues to flourish. He confronts a disoriented Trina with an awkward marriage proposal. Norris chronicles the hapless dentist's attempt to adhere to social conventions:

Listen here, Miss Trina, I like you better than anyone else; what's the matter with us getting married?' Trina sat up in the chair quickly, and then draw back from 
him, frightened and bewildered... No, no, she exclaimed, refusing without knowing why, suddenly seized with a fear of him, the intuitive feminine fear of the male. (Norris 19)

In this sequence of events, McTeague relies on the institution of marriage to legitimize his actions. To sexually assault another is a morally reprehensible act. Thus, McTeague's feeblemindedness allows him to believe that marriage would nullify the negative effects of these actions. Norris's characterization of McTeague as subhuman is instrumental in understanding this sort of behavior. The subhuman specimen resembles beast as opposed to man and must act accordingly. As a female, Trina has stumbled into the lair of a savage creature. Therefore, McTeague believes that he may be entitled to more than financial gains. Norris depicts McTeague as having natural urges. Yet, Norris's understanding of man relies on a constructed system of values. The men of virtue that comprise the upper crust (those supposed paragons of Anglo-Saxonism) of society might have these feelings, too. However, their moral training, the presence of what Louis Althusser calls state apparatuses (both ideological and repressive), and Anglo-Saxon racial hygiene allow the suppression of such feelings.

Utilizing the work of Althusser, one finds that McTeague exhibits behavior conditioned by Ideological State Apparatuses (ISAs) and enforced by Repressive State Apparatuses (RSAs). Althusser defines the two as follows: "What distinguishes the ISAs from the (Repressive) State Apparatus is the following basic difference: the Repressive State Apparatus functions 'by violence,' whereas the Ideological State Apparatuses function 'by ideology"' (Althusser 14). At the simplest level, violence (utilized by the police, army, etc.) enforces any given citizen's behavior and the ISA relies on a process 
of indoctrination to force citizens to adhere to specific social conventions. During and before the marriage proposal fiasco, McTeague's behavior exemplifies the utility of both.

Within the context of Althusser's terminology, McTeague's fear of wrongdoing begins with an ideological struggle. The knowledge of proper courtship rituals surely appeared somewhere in McTeague's socialization. One might speculate that McTeague picked up some idea of morality from his mother or other inhabitants of the mining camp. Althusser states that another difference between ISAs and RSAs is that ISAs usually manifest themselves as private institutions. He lists "the religious ISA, the educational ISA, the family ISA, the legal ISA" (Althusser 13) as just a few examples of those that instill the dominant ideology. The presence of ISAs is evident in McTeague's statements during his early encounter with Trina. Each time that McTeague is tempted, he repeats the phrase: "No, by God! No, by God!" (Norris 17). Despite his limited education, McTeague knows that his actions go against societal laws and the Almighty. These exclamations illustrate McTeague's appeal to a higher authority to save him from his desires.

McTeague's implorations demonstrate the ISAs' influence on society. Simultaneously, McTeague's marriage proposal highlights the presence of RSAs working in conjunction with ISAs. Fearing the weight of sin, McTeague must also beware of police intervention. The police force's state-sanctioned capacity for violence ensures that societal laws are followed. Imprisonment and death are the worst two possible consequences for any given citizen. Yet, McTeague attempts to circumvent these potential consequences. The brawny dentist immediately proposes marriage to the awakened Trina. After manhandling her, McTeague's social training causes him to 
believe that the institution of marriage will wash away his sins. In the Christian tradition, marriage is a union ordained in the presence of God. Therefore, offering marriage allows McTeague to appease the ISAs as well as evade retribution from the RSAs.

Additionally, it is useful to explore McTeague's actions by using Foucault's idea of "Panopticism" as explained in Discipline and Punish. Foucault's assertions apply to the birth of the modern prison system but they also help explicate McTeague. Despite the absence of any witnesses during his violation of Trina, Norris's protagonist still feels the watchful eyes of his society. Through ISAs, McTeague believes the divine acts as a stand-in for the any repressive agent. Foucault explains "the major effect of the Panopticon: to induce in the inmate a state of conscious and permanent visibility that assures the automatic functioning of power" (Foucault 201). Paired with Althusser's ideas, Foucault's statement helps to explain McTeague's understanding of the divine. In the case of McTeague, religious ISAs safeguard the ignorance of the working class. Throughout Norris's novel, a fear of the divine acts as a regulator for the lower classes. (There is also a racial component to the divine that will be explored later in this chapter). McTeague often uses "God" as an interjection. Upon winning over Trina, McTeague first acknowledges his Lord and then comments that she is a quality woman. His victorious cries are as follows: “'I got her, by God! I got her, by God!' At the same time he thought better of himself; his self-respect increased enormously. The man that could win Trina Sieppe was a man of extraordinary ability" (Norris 49). Gratitude is the dentist's primary emotion. As "by God" is a common expression, it also serves to depict McTeague's superstitious nature. For Norris, superstition is a class marker (Zerkow and Maria Macapa are great examples of this). Superior men (Norris seems to channel 
Nietzsche's idea of the Übermensch) rely on logic and avoid this variety of thought. The second component of McTeague's gratitude lies in the affirmation of his self-worth. Since Trina is a woman of superior quality, McTeague delights in winning her over. He relishes the fact that their potential marriage will be the legitimization of his sexual urges. Winning over Trina is an example of how institutions regulate citizens' behavior. Regardless of McTeague's dubious morals, the institution of marriage is a means of providing revenue to the state and a way of policing citizens' sexuality.

The role of institutions continues to affect McTeague's life. Shortly after he wins over her heart, Trina herself wins a lottery prize of five thousand dollars. These winnings appear to be a boon for her future with McTeague. Nevertheless, this wealth proves burdensome. Trina's good fortune draws the ire of her cousin, Marcus. As the man who once sanctioned McTeague's pursuit of Trina, Marcus's true nature is revealed here. He is a petty, vindictive, and jealous man. Instead of congratulating the happy couple, Marcus laments the fact that Trina could have been his. He mourns the circumstances that led to his loss of entitlement. In his simple manner, Marcus considers Trina more as an object than as a person. His cousin's five thousand dollars have transformed her into a valuable commodity. Just as McTeague had done, Marcus also invokes a higher power when mourning the loss of potential financial gain:

You fool, you fool, Marcus Schouler! If you'd kept Trina you'd have had that money. You might have had it yourself. You've thrown away your chance in life-to give up the girl, yes--but this, he stamped his foot with rage- - to throw five thousand dollars out of the window--to stuff it into the pockets of someone else, when it might have been yours, when you might have had Trina AND the money- 
-and all for what? Because we were pals. Oh, 'pals' is all right--but five thousand dollars--to have played it right into his hands-God DAMN the luck! (Norris 74) In a brash manner, Marcus disposes of all his gentlemanly qualities. He considers himself foolish, he loses his "property," and he questions the concept of friendship. In short, the potential of great monetary gain is a dehumanizing prospect. Marcus falls under the spell of irrationality. Thus, he leads himself to believe that McTeague must have swindled him. Marcus's adherence to the conventions of honor did not allow for a level playing field. The belief that McTeague's treachery stifles Marcus's economic growth gives birth to a vengeful nature. Because of this alleged dishonesty, Marcus seeks McTeague's ruin.

Now in direct competition with McTeague, Marcus utilizes the budding institution of medical regulatory boards to exact revenge upon the unwitting dentist. Yet, before Marcus takes revenge, McTeague will embarrass him once more. As the marriage to Trina causes irreconcilable differences between the dentist and Marcus, petty alcoholfueled skirmishes occur in Joe Frenna's Saloon. These quarrels take a more violent turn when Marcus pulls a knife on McTeague. However, this conflict serves as a precursor to a bloody wrestling match during an excursion at the park. Marcus, McTeague, Heise, and Ryer set up an impromptu wrestling tournament. In the spirit of recreation, these four men engage in bouts of physical combat. Marcus and McTeague quickly dispatch their respective opponents. Norris utilizes all of Marcus's ill will to construct a brutal match between two former friends. As a result, this wrestling match also reveals the baser natures of both characters.

In the struggle for economic resources, the wrestling match serves as a symbol of how institutions act as catalysts in human behavior. Marcus is frustrated at his inability to 
gain Trina's five thousand dollars and sees the wrestling match as a way to reassert his masculinity. Once an honorable and likable character, Marcus's sense of honor is discarded in one fell swoop: “'God damn you! get off of me,'... With the oath Marcus had twisted his head and had bitten through the lobe of the dentist's ear. There was a sudden flash of bright-red blood" (Norris 133). Unable to escape from McTeague's grasp, Marcus resorts to an illegal tactic in an attempt to gain the upper hand. The searing pain from Marcus's bite results in the emergence of McTeague's beast-like qualities. However, Marcus's action of frustration shows how a seemingly civilized man may employ unsavory tactics in the pursuit of economic prosperity. Norris uses Marcus as a counterpoint to McTeague to show that humans are never quite above their basest instincts.

In describing McTeague, Norris rarely shies away from using animalistic comparisons. When the burly dentist sustains Marcus's bite during their melee, Norris utilizes animal imagery: "It was the hideous yelling of a hurt beast, the squealing of a wounded elephant. He framed no words...It was something no longer human; it was rather an echo from the jungle" (Norris 133). Marcus's treachery causes McTeague to figuratively revert to a lower life form. His cries are inhuman. Moreover, these yelps are the prelude to McTeague's descent into true savagery. Flailing about, the crazed dentist breaks Marcus's arm and needs to be restrained by the surrounding men. McTeague's rage manifests itself in a different manner than Marcus's. Whereas Marcus becomes petty and conniving, McTeague's inner nature is ferocious and violent. Both of these varieties of rage are unproductive in society. In Norris's depiction of man as animal, the intent to destroy is an inherent trait. 
Following the conclusion of this violent incident, an event is set in motion that will forever alter McTeague's destiny. The wrestling match was a pyrrhic victory for the dentist. While Marcus regains his strength, McTeague and Trina live a relatively good life as the dental business thrives. Also, Trina invests the principal of her lottery winning in her Uncle Oelbermann's toy store in the Mission District. As a display of their upward social mobility, the pair decide to move into a home of their own. Their prosperity is fleeting as McTeague receives a letter from city hall. Confused by the letter's contents, McTeague presents it to Trina: "The letter- or rather printed notice- informed McTeague that he had never received a diploma from a dental college, and that in consequence he was forbidden to practise his profession any longer" (Norris 146). This portentous letter sends McTeague into a downward spiral. Barred from his vocation, the couple face eviction from their home and sell most of their possessions.

City hall's cease-and-desist order bars McTeague from continuing to practice unlicensed dentistry. In this unfortunate series of events, McTeague faces the legal ramifications that city hall can impose on him. Therefore, the dental association and city hall crush McTeague's autonomy. His lack of proper credentials now obstructs his primary means of obtaining capital. Using these events as an example of institutional power, Norris shows how government intervention can infringe upon the welfare of an individual. Although not the brightest, McTeague is competent in his trade. Marcus, Trina, and many others have endured his procedures. Yet, this does not bestow legitimacy upon McTeague.

Upon reading this letter, McTeague is unable to understand its purpose. His inability to understand draws the ire of Trina. On the origins of his dental knowledge, 
McTeague states that he "went along with a fellow who came to the mine once. My mother sent me. We used to go from one camp to another" (Norris 147). In this statement, McTeague further explains his induction into the dental trade. His lack of credentials is due to his lack of formal education. However, McTeague still acted as an apprentice to a self-declared dentist. Apprenticeships were once the primary means of learning any trade. As such, McTeague's mother thought it logical to send her son to travel alongside a traveling dentist. Thus, his upbringing is directly influenced by economic and temporal circumstances.

Roughly thirty years old at this point in the novel, McTeague was raised in a time period where official certification was unnecessary. The present-day requirements of most medical disciplines were at a relatively early stage of development. According to Bernhard Weinberger's An Introduction to the History of Dentistry, American medical certification was in its infancy in the nineteenth century. He writes: "About 1840, when dentistry in America began to emerge as a distinct and separate profession, the dentist himself still continued to practice all of its branches under the name of general practitioner" (Weinberger 3). He continues his explanation by noting that dentistry became more specialized around 1900. These statements help to contextualize McTeague by adding a real-world example of how the dental trade evolved. In McTeague's conversation with Trina, the soon-to-be former dentist lacks any understanding of these educational requirements: “"Huh? What? College? No, I never went, learned from the fellow...' 'But do you know you can't practise unless you're graduated from a college? You haven't the right to call yourself, “doctor.'... 'Why I've been practising ten years. More-nearly twelve.' 'But it's the law.' 'What's the law?'” (Norris 147). If he had 
trained under a legitimate professional, McTeague's experience might be sufficient to earn the proper credentials. Thus, this is an example of how professionalization might harm the lower classes. As the underprivileged could no longer practice trades deemed professional (this was also linked to Progressives' efforts to protect public health), some relatively skilled persons lost their vocations.

Over the course of American history, regulatory bodies have developed to combat poor and potentially dangerous practices. During the early twentieth century, businesses, hospitals, and factories were subject to sweeping reforms. Although legislation and regulation would aid American men and women, McTeague is a victim of the times and of betrayal. Marcus's malevolent actions affect McTeague's wallet and sense of pride. His objective to rob McTeague of his livelihood has its foundation in the American economic system. Yet, Marcus feels justified in his actions because McTeague stole away his golden goose.

All of these results reflect Josiah Strong's and other Progressives' ideas of reform. Urban life, existing institutions, and vice are all markers of the individual's destruction. Trina's remarks- "It's Marcus that done it" (Norris 148)-highlight the beginning of their demise. This sudden realization of Marcus's betrayal violates both familial ties and the bond of friendship. Seeking work as a rancher, Marcus leaves McTeague and Trina on amiable terms. Yet, Marcus uses their false sense of security to deliver a crushing blow. Marcus's act results in the gradual undoing of the Trina-McTeague marriage. Facing economic difficulties, their relationship disintegrates. Trina refuses to use their lottery savings and McTeague continues to abuse alcohol. Fueled by alcohol, the loss of his possessions (he is especially infuriated by the loss of his concertina), and Trina's 
parsimonious attitude, McTeague's sense of morality finally crumbles. The former dentist completes his devolution and beats Trina to death. Now more beast than man, McTeague continues living by taking menial jobs and fleeing from the authorities (RSAs). His impoverished existence continues until he presumably meets his end in Death Valley with Marcus's corpse shackled to his body. McTeague experiences a loss of his vocation and possessions, the power of institutional regulations, and the fierce competitive nature of urban life.

\section{Race, Social Gospel, and Urban Life}

Race and vice are two indispensable properties of Josiah Strong's writings. In Our Country, just as with McTeague, Strong focuses on how alcohol and race play a role in the society's undoing. The inflammatory clergyman writes, "Is there any room for reasonable doubt that this race unless devitalized by alcohol and tobacco, is destined to dispossess many weaker races, assimilate others, and mold the remainder, until, in a very true and important sense, it has Anglo-Saxonized mankind?" (Strong 178). For Strong, vice and urban life are two factors threatening the Anglo-Saxon. Norris captures this idea in his prose. Race becomes an integral part of McTeague. The various ethnicities present in the novel exemplify Strong's anxieties about vice and urban life. For example, Marcus and Trina are of German extraction with unclear ties towards Protestantism. To complicate all of this, Trina's father is of Swiss-German descent and is still a staunch Catholic. Moreover, Heise and other Germans of the novel all display a fondness for alcohol. Maria Macapa, the Mexican maid, and Zerkow, the Polish Jew, possess a tremendous hunger for wealth. All of these vices, however, are not the sole possession of 
one ethnic group. Trina possesses the same materialism and parsimony as Maria and Zerkow, while McTeague's fondness for drinking almost surpasses that of the German characters.

Beginning with the hapless dentist, McTeague's ethnic origins are shaky at best. As explained earlier in this chapter, McTeague's traits are stereotypically Celtic. The dentist is a hard worker, but dull-witted, and is prone to overindulgence. His presence reflects Strong's anxieties about the sanctity of the Anglo-Saxon race. Aside from his brute strength, McTeague possesses very undesirable traits. His vice and lack of intelligence are the polar opposite of Strong's idealized Anglo-Saxon. While those with Celtic traits may resemble Anglo-Saxons, they lack the portion of Germanic blood that Strong and his contemporaries believed to be the origin of their alleged supremacy (as discussed more fully in the next chapter). However, McTeague's weaknesses are just one facet of Strong's anxiety.

Norris creates other extreme examples of those supposed traits of inferiority. Trina Sieppe and Marcus Schouler possess more Germanic blood than the exalted AngloSaxon. Yet, Marcus is prone to alcoholism and harbors a greater sense of greed than McTeague. This type of greed towards monetary gain is apparent in Trina as well. When informed that McTeague has been ordered to halt practicing dentistry, Trina states: “'Oh, if you'd only killed Marcus Schouler that time he fought you'" (Norris 149). Trina becomes bloodthirsty when the situation pertains to her livelihood. In pursuit of capital, rationality is discarded. Marcus and Trina do not possess any common sense in their pursuit of wealth. While Trina takes advantage of McTeague's lack of intellect, she places both of their wages in a chest where it is never utilized to better their lives. On the 
other hand, Marcus's malice indirectly leads to Trina's murder. While he could have halted his revenge by destroying McTeague economically, Marcus chooses to track him down in an attempt to reclaim the remainder of Trina's lottery winnings. This action leads to what Norris may have intended as a travesty of the clichéd western standoff where McTeague emerges as the temporary victor. From these examples, it would seem that Marcus and Trina's actions are the direct result of their ancestry. Their inclinations toward materialism are the exact self-destructive traits that Strong warns his readers about.

Similarly undesirable traits are apparent in Zerkow. The Polish Jew works as a junk dealer and lives in squalor near McTeague. Norris utilizes the phrase "the cat-like lips of the covetous" (Norris 25) to emphasize Zerkow's predatory nature. Although Marcus and Trina display similar emotions, Zerkow's "keen eyes" and "claw-like, prehensile fingers" (Norris 25) reflect his greed. The desire for gold supplants all of his other desires. However, Zerkow's greed festers within him until he begins a relationship with Maria Macapa. As the pair shares glasses of whiskey, he is beguiled by her stories of her family's lost wealth. Maria's family once owned vast amounts of gold plates and other artifacts. This story of lost wealth entrances Zerkow to the extent that he demands Maria to retell it repeatedly.

It is unclear whether Maria fabricates the narrative of her family's wealth, as it is also unclear what exactly her ethnic origins are. Along with her penchant for telling stories, Maria has a tendency to speak in bizarre non-sequiturs. In one instance, she remarks that she "had a flying squirrel and let him go" (Norris 25). Combined with her desire for wealth, Maria Macapa is of mixed race, and is potentially mentally unstable. In 
this respect, she can be seen as the female equivalent of Zerkow. The pair exhibits a hybridity that would have offended the Anglo-Saxon sensibilities of Strong and the exponents of race science. Moreover, she utilizes this story and her appearance for some degree of upward mobility. Her mysterious qualities become exotic to Zerkow: "She suddenly appeared from the unknown, a strange woman of mixed race, sane on all subjects but that of the famous service of gold plate; but unusual, complex, mysterious, even at her best" (Norris 27). Here, Maria's characterization tends to show that there is an aspect of her that is not quite right. Along with Zerkow, their genes are supposedly hybrids of disparate parts (Polish and Jewish, Spanish and Native American).

Throughout Norris's novel, this type of hybridity and miscegenation is only possible in an urban space. Zerkow and Maria Macapa's relationship embodies the fallacious and hate-filled idea that the mixing of ethnicities will diminish humankind's potential. First, however, is the dismantling of Zerkow and Maria's marriage. The event that sets this collapse in motion is Maria's apparent memory loss. Zerkow demands that Maria retell the story of her family's lost riches. The junk dealer is alarmed to find that Maria claims not to remember the story and questions his understanding of reality. The statement that signals trouble is as follows: "'I don't know what you're talking about Zerkow... There never was no gold plate. No gold service. I guess you must have dreamed it"" (Norris 135). With these statements, Maria crushes the only tale that brings Zerkow joy. Both individuals demonstrate a limited grasp on reality and thereby foreshadow the unfortunate results of their procreation.

The offspring of Zerkow and Maria does not live for a long time. Shortly after the birth of their child, it has "not even enough strength nor wits enough to cry" (Norris 135). 
Zerkow views the baby as an economic drain while Maria goes into a state of insanity for a period of ten days. She only recovers to make arrangements for the burial of the child. For the duo, this was an inconsequential birth. Norris's description of these events are more disturbing than Zerkow and Maria's reactions: "It had not even a name; a strange hybrid little being, come and gone within a fortnight's time, yet combining in its puny little body the blood of the Hebrew, the Pole, and the Spaniard" (Norris 135). If one considers Norris's earlier remarks that Maria was a woman of mixed blood, it seems peculiar that Norris makes no mention of the indigenous Central American blood. This erasure of the Native American blood suggests that the amount of hybridity within the child was already flawed. Even without Native blood, the child's fate would still result in death because of its parents' health and the San Franciscan environment.

Putting aside the problematic depiction of racial intermingling in this episode, Maria and Zerkow are the only two characters in the novel that procreate. McTeague and Trina's sex life is never directly discussed. Rather, McTeague is described as a beast and Trina is described as having an infantile appearance. The economic issues play a much larger role in their lives. For instance, Trina mourns the loss of the money that McTeague stole as if she had lost a child. Norris utilizes this reaction to show a case of maternal instincts manifesting themselves in an abhorrent way. In this regard, Norris's San Francisco becomes a place of human waste. Norris sees no value in this alleged cesspool of hybridity. Nature cannot do its duty and the human race faces great obstacles in both economic and ethnic struggles.

In Norris's incarnation of San Francisco, all of Strong's anxieties play out. There is a clear presumption that alcoholism, greed, and miscegenation serve as the markers of 
urban life. As Zerkow's and McTeague's relationships with women both end with murder, Strong's idea of Anglo-Saxon superiority (and the failure of supposed inferior ethnicities) is exemplified in Norris's gritty naturalist novel. In every sense, Norris's novel utilizes fallacious logic to serve as a cautionary tale for the Anglo-Saxons of Northern California. For Norris and Strong, societal decay is fueled by the fear of change, the influx of immigrants, and the presence of miscegenation and economic inequality. 


\section{CHAPTER II: WHITENESS IN LONDON'S THE VALLEY OF THE MOON}

In Jack London's The Valley of the Moon (1913), protagonists Saxon Brown and Billy Turner begin their married life together as members of the working class in turn-ofthe-twentieth-century Oakland. London's two proletarian protagonists, Saxon and Billy, are exemplars of their "Anglo-Saxon" heritage. Throughout American history, the characteristics of Anglo-Saxons are constructed to be those with Germanic-English ancestry who share blood with the early conquerors of England. Channeling David Roediger's The Wages of Whiteness, Andrew Gyory's Closing the Gate states:

"Whiteness provided psychological distance from blacks and elevated white workers, especially Irish immigrants, to a common equality as American citizens (Gyory 14). In London's novel, there is a constant reiteration of this commonality as Anglo-Saxons. Saxon and Billy believe Anglo-Saxons are the lone founders of the American nation. The Anglo-Saxon desire to expand their territory brought Saxon and Billy's ancestors to the American West. The pair remembers their relatives as those without fear of any enemy, land, or social condition. By not forgetting the old ways, this ideal Anglo-Saxon couple's wanderings are London's method of reeducating his readership. The Anglo-Saxons who tamed the West were resilient and possessed an innate set of survival and subsistence farming skills. In various manners, The Valley of the Moon glorifies the more insidious ideals of the Progressive Era. Throughout this chapter, I will describe how Saxon and Billy believe that the Anglo-Saxons' decline is due to administrative ineptitude, which is a view that was also held by the Progressives of the early twentieth century.

Through Saxon, London idealizes the Anglo-Saxon heritage of the Early United States. Saxon provides a romantic depiction of her ancestry: 
"The Saxons were a race of people- she told me all about them when I was a little girl. They were wild like Indians, only they were white. And they had blue eyes and yellow hair, and they were awful fighters." As she talked, Billy followed her solemnly, his eyes steadily turned on hers. "Never heard of them," he confessed. “Did they live anywhere around here?" (London 17)

In this description, Saxon retells her mother's story to illustrate the supposed innate strength of their race. The legacy of the Anglo-Saxons exists as an oral tradition. Saxon's mother was a poet who romanticized American conquest. Inheriting her duty as an Anglo-Saxon racial historian from her mother, Saxon must also live up to the significance of her first name. Assigning the duty of racial purity to females has a solid foundation in American art and literature. Thomas C. Leonard points this out in his Illiberal Reformers. Scholars, Politicians, Economists, and Eugenicists all subscribed to a "mother-of-the race" argument (Leonard 170). Around 1908, scholars such as John R. Commons (a Progressive economist) and Edward A. Ross (a Progressive, Sociologist, and Eugenicist) asserted that women were the guardians of the race. While their approaches to women's wages differed, these two men displayed great anxiety about the future of the AngloSaxon race.

Rooted in uncertainty, the figure of the woman as a guardian of the race is common to this novel, American politics, and art. Descriptions of Saxon include stereotypical Northern European features associated with Anglo-Saxons. Her fair hair and light eyes indicate Germanic features. While this physical description is commonly found in political rhetoric, John Gast's painting, American Progress (1872), displays a female figure that represents the personification of Manifest Destiny. Columbia, the 
figure in the painting, is clad in virginal white and has flowing fair hair. At her feet, settlers and covered wagons move across the landscape as Native Americans flee from her course. As a beacon of the Anglo-Saxon people, Columbia presses onward into the unknown directing Anglo-Saxon conquest. In art, literature, and politics, Anglo-Saxon women are glorified. In these depictions, it is their theoretical duty to serve as custodians of the race. In terms of literal reproduction, Anglo-Saxon women must be keen enough to choose appropriate breeding partners. Therefore, in her conversation with Billy, Saxon gauges his eligibility as a romantic partner. As a guardian of white Anglo-Saxon womanhood, Saxon must verify a potential suitor at any given time.

Coupled with the ethnic vetting, this conversation also reveals London's anxieties about the continuation of Anglo-Saxon dominance. With features reminiscent of Norsemen, Saxon asserts that Anglo-Saxons may disappear from the Earth. Notably, Saxon compares the Anglo-Saxons to Native Americans. In London's era, Native Americans were often admired as a race that was on the brink of extinction and refused to succumb to the evils of miscegenation. As Michael H. Hunt points out in Ideology and U.S. Foreign Policy, late nineteenth-century white Americans considered Native Americans to be tragic figures. London utilizes these sentiments to warn readers that the Anglo-Saxons face a similar plight.

For London, Native Americans and Anglo-Saxons are not entirely incompatible. Rather, London's attitude reflects the common views of many nineteenth century Americans. Within Ideology and U.S. Foreign Policy, Hunt explains: "In the course of the nineteenth century whites showed a generous impulse, the prerogative of victors, to downplay old antagonisms and assign the Indian a flatteringly high place in the hierarchy 
of race" (Hunt 55). Some nineteenth and twentieth century writers (Helen Hunt Jackson and Willa Cather, for example) would pay homage to the Native Americans. Although it was published slightly later than The Valley of the Moon, Walter Benn Michaels writes extensively on Cather's The Professor's House and its sympathetic portrayal of Native Americans. Whereas Jackson and Cather's writing reflected a changing perspective of the very ethnicity that was once considered the greatest of enemies, London's comparison of Native Americans and Anglo-Saxons exemplifies the idea that Anglo-Saxons face extinction. However, the prevailing idea of London's era as explained by Hunt is "that general law of nature: where two races meet, the inferior yields inevitably to the superior" (Hunt 58). Saxon serves as a mouthpiece for this idea. In an early scene of the novel, Saxon and her friend Mary attend the Oakland Bricklayers gathering with Billy Roberts and Bert Wanhope. At first glance, this is a simple meeting of friends. During the festivities, London reveals the Anglo-Saxon heritage of the group. These individuals are paragons of hope for the continuation of a supposedly superior race. Billy and Saxon's relationship is founded on this idea of racial superiority. After all, Billy states that “...we old Americans oughta stick together don't you think? They ain't many of us left. The country's fillin' up with all kinds of foreigners" (London 20). Billy and Saxon employ Said's tactic of the other, a concept that is integral to Anglo-Saxonism and London's novel.

\section{Said, Orientalism, Anglo-Saxonism, and Race in Oakland}

Continuing their discussions of ethnic origin, Saxon explains to Billy their collective heritage as true Americans: "“No. They lived in England. They were the first 
English and you know the Americans came from the English. We're Saxons, you an' me, an' Mary, an' Bert, and all the Americans that are real Americans, you know, and not Dagoes and Japs and such"' (London 17). Here, Saxon makes use of Edward Said's concept of othering. In Saxon's rhetoric, Billy can establish his cultural heritage by identifying those whose appearances and heritage differ from his own. Thus, true Americans can only come from the vaunted Northern European stock.

Edward Said's Orientalism is centered upon the supposed binary of the Orient and the Occident. Said's ideas are more about power dynamics and how European powers carved up the world and prioritized the value of their own cultural achievements. Said asserts that Americans' proximity to the Orient is limited and that his ideas more aptly apply to Europeans. Nevertheless, Said's statement that "the Orient has helped to define Europe (or the West) as its contrasting image, idea, personality, [and] experience" (Said 2) provides an avenue with which to explore American Anglo-Saxonism. During the latenineteenth and early-twentieth centuries, Americans utilized a form of what Said describes in order to delineate the hierarchy of the world's races, which were increasingly migrating to the United States.

In defining the history of the United States of America, London uses Saxon and Billy to characterize it as a state of citizens with English blood. As immigrants accumulated within the nation, nativists feared for the dilution of English blood. This notion is oft repeated throughout The Valley of the Moon. First, in the aforementioned exchange between Billy and Saxon, Billy expresses ignorance about the duo's AngloSaxon heritage stating: "NNever heard of them, he confessed. Did they live anywhere around here?"' (London 17) There are two ideas at play in Billy's admission. First, this 
statement is supposed to be shocking for London's contemporaries. Upon deconstruction of Billy's statements, a present-day reader observes an anxiety hidden in London's writing. The tension is that uncertainty about heritage is dangerous for the greater good of the Anglo-Saxons. Second, London's intention is to stoke the fear in his readers. His statement employs language to show how the Anglo-Saxons have now cemented their status as the new form of Native Americans. Without vigilance, the Anglo-Saxon may be doomed to go the route of a former adversary.

Another intriguing aspect of Saxon's racial explanations is contained in her surname. "Brown" is perhaps one of the most common surnames in English-speaking countries. There is, however, a certain irony in this Anglo-Saxon surname. On one hand, Saxon serves as the epitome of purity and whiteness in the novel. On the other hand, her surname connotes the perceived darker enemies of the Anglo-Saxon race. In a sort of Saidian manner, Saxon knows that "Brown" is the other and is undesirable. Upon their marriage, Saxon literally eliminates her surname by becoming Mrs. Roberts. Her name is symbolic of the American power structure of the period. Saxons must take a priority over those around them.

After discovering Billy’s racial ignorance, Saxon demonstrates how the AngloSaxons define themselves. She states that they are descendants of the original EuropeanAmericans. Despite their low socio-economic status, Saxon shows how Billy and their companions occupy a higher echelon of society as compared to those of other ethnicities who are of a similar class. Many of the ethnic groups in Oakland (Italians, Irish, Chinese, Japanese, etc.) are characterized as undesirable. Rather than consider these ethnicities as fellow human beings, Saxon and the other characters only view these groups in terms of 
how they are competing for the scarce resources of employment and housing. In spite of their current misfortunes in urban Oakland, Saxon believes that she and Billy are equipped with superior traits that will allow upward mobility.

\section{Progressivism, Labor, and Race}

Since Billy Roberts is unaware of the Anglo-Saxons' supposed innate capacity for achievement, Saxon illustrates what many Progressives were afraid of. Urban centers, such as Oakland, were thought of as cesspools filled with miscegenation, poverty, and alcoholism. Furthermore, some economists, such as Francis Amasa Walker and Richmond Mayo-Smith (as well as clergyman, Josiah Strong), thought of cities as the quintessence of human misery. For good Anglo-Saxon workers, the playing field was supposedly tilted towards the unruly masses of immigrants from Europe, Asia, and Central America. All of these issues were of great concern to politicians and intellectuals of the era. Thus in London's novel, the concerns of the Progressive movement, which took place between roughly 1890 until 1920, are readily apparent.

In Illiberal Reformers, Thomas C. Leonard offers an overview of the economic, racial, and social policies associated with the Progressive movement. According to Leonard, "Progressivism's braiding together of the admirable and the reprehensible starts with its veneration of science. There can [be] no doubt that the progressives in economic reform drew deeply on race science and eugenics to distinguish the victims who deserve uplift from the threats who required restraint" (Leonard 189). For the Progressives, the Anglo-Saxons were in need of uplift, an idea that is reminiscent of Josiah Strong's notion of the Social Gospel, which asserted that society on Earth could be perfected. It was also 
their belief that appointing experts to administrative positions could help alleviate the decline of the Anglo-Saxon. Many Progressives clung to the core notion that society should work for all men, women, and children. However, many had a specific group in mind. In the predominant variety of Progressive thought, Anglo-Saxons were the quintessential Americans and therefore should be the sole beneficiaries of social uplift.

The key elements of the Progressive movement were professionalization, reformation, and regulation. Progressives believed that college-educated economists were necessary to the success of the nation and could help to alleviate the ills of labor, wages, and the working class. Alongside professionalization, Progressives asserted that certain aspects of society could be reformed to work more efficiently. For example, Leonard indicates in Illiberal Reformers that the Interstate Commerce Commission (ICC) was seen as a "Fourth Branch" of government that could ensure the success of the judicial, legislative, and executive branches. Through stricter administration and regulation of laissez-faire capitalism, society would improve for the Anglo-Saxon contingent of the population.

The Valley of the Moon posits that lesser races were usurping the reign of the Anglo-Saxon, but this idea was not limited to this novel alone. In fact, London's views were quite common. As noted by Leonard, Darwinism played an important role in economic and social policies of the era. To show Darwinism's role in Progressive thought, Leonard quotes two Progressive leaders, Richard T. Ely and Edward A. Ross: “"the State is [a] moral person.' Social scientists must recognize, Ross wrote in Social Control, that society was not just 'a bunch of persons!' Society was rather, 'a living thing, actuated, like all other higher creatures by the instinct for self-preservation"” 
(Leonard 101). For Progressives and London, Anglo-Saxons helped to make up a larger social organism that they needed to maintain mastery over.

In the political thought of London's era, society was often characterized as an organism. Darwinism taught Progressives that organisms must be free from disease to reach evolutionary perfection. For Leonard, the organism comparison was essential to the success of Progressivism:

Depicting society as an organism was a rhetorical masterstroke. The social organism implied that the American nation was as unified as an organism, with instincts of self-preservation, purpose, and a conscience. The social organism affirmed progressive anti-individualism by subsuming corporate and natural persons alike. The social organism also lent vital credibility to the progressive idea of the state administering economy and policy for the good of all... What is good for the organism is good for its constituent parts... And an organism has well-defined boundaries. Its native cells belong in it, but foreign parasites and microbes did not belong and were a threat to the organism's health and integrity. (Leonard 106)

Throughout The Valley of the Moon, London shows the disgraceful conditions of laborers within Oakland. Overcrowded streets, lack of adequate food supplies, and disease are some of the hardships mentioned in the novel. While the conditions are deplorable for members of all races, the novel centers upon the struggles of Anglo-Saxon whites. There is a great deal of nostalgia throughout the novel that echoes the mindset of a large portion of Progressives. In one example, Billy shows a great fondness for the folklore of his people: "I like to hear about the old people of the old days. My people was along in there 
too, an' somehow I think it was a better world to live in than now... But it's like this: I don't understand life today. There's the labor unions an' employers associations, an' strikes, an' hard times, an' huntin' for jobs an' all the rest'” (London 53). In this sequence, Billy Roberts expresses the same nostalgia felt by many Progressives, but this nostalgia is built on falsehood and fuels Anglo-Saxonism. Subsistence farming and colonizing the American West were not leisurely tasks. London romanticizes the past through Billy; it was a past fraught with danger, bloodshed, and suffering. However, in the minds of Saxon and Billy (along with the Progressive reformers of London's day), a homogenous Anglo-Saxon nation was the key for present and future success.

According to the Oxford English Dictionary, the word nostalgia contains two Greek etymons. First, nostos, means to return home. The suffix, algia, signifies pain. In this above excerpt, Billy's lament echoes the idea that modern conveniences and institutions are ill equipped to provide relief to the citizens that are in most need of assistance. As illustrated in The Valley of the Moon and in the writings of multiple Progressives, modern institutions seem to have failed the Anglo-Saxon race. Society was in decline because of this alleged institutional ineptitude. In Progressive logic, institutions that failed the superior members of society were in need of reform.

As a result of Billy and Saxon's trials in the city, Saxon comes to that conclusion that they must leave it to find a better life. London's use of free indirect discourse through Saxon suggests a rejection of modernity: "The city was no place for her and Billy, no place for love nor for babies. The way out was simple. They would leave Oakland" (London 218). Reiterating the idea that cities are cesspools, Saxon believes in a return to a rural preindustrial lifestyle. Billy and Saxon's ideal lifestyle would embrace 
London's paradigm of a more primitive (or natural) form of existence. This lifestyle would be defined by an agriculture-based economy, close proximity to the land, a fair division of labor, and Anglo-Saxon homogeneity.

Saxon's lexicon highlights this wish for Anglo-Saxon homogeneity. First, the city is not appropriate for Billy and Saxon. Its pollution, unfair division of labor, and ethnic minorities produce an unsuitable atmosphere for Anglo-Saxon prosperity. Not long after having a miscarriage, Saxon's sentiment casts the city as "no place for love nor for babies" (London 218). Saxon mentions both love and procreation. By implication, Oakland's struggles are meant for those of other races. Pure Anglo-Saxon affection and romance cannot flourish when surrounded by racial others. Coupled with marital discord, Oakland is also unsuitable for children. Oakland is a city without love and filled with ethnic minorities. Here, London aligns himself with the nature side of Galton's "nature versus nurture" debate. Billy and Saxon must have children that are raised closer to the land to reclaim their heritage. Thus, children born in rural municipalities will unlock their instinctive agricultural and combat skills. As a prospective mother, Saxon's instincts are the key to preserving pure bloodlines. Along with her Anglo-Saxon proclivity for agriculture, Saxon exhibits the desire for racial purity that was common among eugenicists.

\section{London's Oakland, An Anglo-Saxon's Duty, and Problems of Racial Classification}

Saxon demonstrates anxiety about racial diversity similar to that of various Progressives. Race scientists, eugenicists, economists, and presidents trembled at the prospects of race suicide and miscegenation. Among these individuals numbered Richard 
T. Ely, John R. Commons (another Progressive Economist), Edward A. Ross, and President Woodrow Wilson. It is, however, William Z. Ripley's The Races of Europe (1899) that provides the racial hierarchy that is evident in The Valley of the Moon. In Ripley's catalog of the races, Caucasians were divided into three separate categories. These included the Alpine, Teutonic, and Mediterranean races. London's character descriptions often align with Ripley's notions, as for instance in Ripley's section on the British Isles:

Nothing could be more convincing to the student of physiognomy than the contrast between many of these faces which we have just described, and those of the typical Anglo-Saxons at Page 308. Of course by reason of their blondness, often really florid, and the portliness of their figures, we immediately recognise them as Teutonic (Ripley 331).

While Ripley's pseudo-scientific study categorizes the Anglo-Saxon as Teutonic, London utilizes the same characteristics to highlight Saxon and Billy's appearances. Upon Saxon's first meeting with Billy, London utilizes a description that adheres to Ripley's racial paradigm. London's focus on blondness is apparent as Saxon was “...startled by a glimpse of his hair — short and crisp and sandy, hinting almost of palest gold save that it was too flaxen to hint of gold at all" (London 13). London's artful description of Billy's appearance contains a level of sophistications that also aligns with eugenic classifications.

Coupled with Ripley's racial classification system, future president Woodrow Wilson's The State: Elements of Historical and Practical Politics (1889) outlined a key characteristic of the English race. For Wilson, the English race was characterized by an 
inherent rationality. Throughout The State, he explains the development of government over the ages and how various races have contributed to these systems. He writes that the purpose of his book is to examine the level of fitness in the English race's administrative capabilities and to avoid the pitfalls that accompany ignorance. Wilson frequently extols the virtues of the English race and its place in the world. On English colonialism, he writes: "Doubtless the most significant and momentous fact of modern history is the wide diffusion of the English race, the sweep of its commerce, the dominance of its institutions, its imperial control of the destinies of half the globe" (Wilson 439). For Wilson and other intellectuals of the period, English dominance was legitimized by the imperial legacy of the English.

The history of English imperialism and conquest found a perfect mate in the philosophy of Social Darwinism. Wilson (and hundreds of others) argued that heredity is evidence in support of Anglo-Saxon dominance. Thus, it was thought that the preservation of Anglo-Saxon genes would propel the human race to greater heights. These arguments were fundamental to the Progressive Movement, making Progressivism a bit of a misnomer as some champions of Progressive politics only concerned themselves with the progress of the Anglo-Saxon.

Moreover, for many Progressives, involvement in the affairs of Anglo-Saxon Americans was not only in their own interests but also for the supposed benefit of all mankind. The duty of the Progressive and the Anglo-Saxon is evident in Saxon and Billy's behavior throughout The Valley of the Moon. During Billy's time in prison for assaulting a strikebreaker, Saxon lives with greater hardship than ever before. She succumbs and must live "like the Italian and Portuguese Women, [as] she gathered 
driftwood and carried it home, though always with shamed pride" (London 207).

Although facing hardship, Saxon relies on her inherent Anglo-Saxon survival skills while simultaneously clinging to the romantic notions of the great Anglo-Saxon.

Part of Saxon's indoctrination of Billy into the fraternity of Anglo-Saxonism is her sense of duty to her race. As with Wilsonian and Progressive ideals, Saxon spreads knowledge of the Anglo-Saxons like a preacher of eugenics on a mission to redeem the whiteness of the American West. Shortly after gathering driftwood as an Italian woman might, Saxon encounters a young man who reaffirms her inherent purpose in the world. This youth, Jack (who is partially based on a younger Jack London), is self-sufficient. He owns a little boat, fishes in San Francisco Bay, and educates himself with books from the public library. During Saxon's encounter with Jack, she asks: “'Did you ever hear of the Anglo-Saxons?"' (London 213). This is a question that Saxon will ask whenever possible. As with Billy, Saxon sees an opportunity to eradicate ignorance of Anglo-Saxon heritage.

A potential Anglo-Saxon mother figure, Saxon's racial awareness is the key to the continued survival of their shared bloodline. For her to approach Jack with this information is a learned behavior. However, for London and Progressives, this is an ideal behavior. To Saxon's surprise, Jack demonstrates extensive knowledge of his heritage. His response to her inquiry is: “"You bet... I'm an Anglo-Saxon, every inch of me. Look at the color of my eyes, my skin, I'm awful white where I ain't sunburned... I'm AngloSaxon. I am of a fighting race. We ain't afraid of nothin'. This bay_think I'm afraid of it!"” (London 213). For Saxon and Jack, the Anglo-Saxon is more than appearance. Complexion, eye, and hair color are only one component of it. The Anglo-Saxon identity 
must also include superior fighting skills, courage, and a penchant for sailing and exploration. In Jack's mind, these traits enabled his and Saxon's ancestors to forge the United States of America. Jack describes his lineage as purely American. To highlight this point, Jack's father fought in the Civil War and his grandfather is described as having killed a man in a standup fight with a blow of his fist when he was sixty years old. An' when he was seventy-four, his second wife had twins, an' he died when he was plowing in the field with oxen when he was ninety-nine years old. He just unyoked the oxen, an' sat down under a tree, an' died there sitting up. An' my father's just like him. He's pretty old now, but he ain't afraid of nothing. He's a regular Anglo-Saxon, you see. (London 213)

London utilizes hyperbole to accentuate the ideal attributes of any given Anglo-Saxon. Although these characteristics are the musings of an adolescent, it is clear that longevity and innate strength are what London thinks allowed the conquest of North America. Appearance as well as these intangible qualities composed the ideal American. These Americans facing hardship could always rely on their supposed inherent superiority. Along with appearance and demeanor, Jack lists numerous Anglo-Saxons to prove his point. A propensity for expansion and warfare allow the Anglo-Saxons to prosper. Describing his nautical exploits, Jack finds it useful to compare Anglo-Saxons and "squareheads" (generally those of Scandinavian heritage). Jack believed that these "squareheads" (while not quite as despised as other ethnic groups) were less accomplished. In Jack's opinion: "Why we licked their kind thousands of years go. We lick everything we go up against. We've wandered all over the world, licking the world. On the sea, on the land, it's all the same" (London 213). As with Said's ideas of the other, 
Jack uses the Scandinavians to show the Anglo-Saxons' place in the upper strata of the racial hierarchy. To complete his argument, Jack lists historical figures Lord Nelson, Davy Crockett, and Kit Carson to add a racial pedigree to the Anglo-Saxon curriculum vitae. As Saxon spreads the Anglo-Saxon history, Jack demonstrates how the AngloSaxons attained their privilege within society. These statements also explicate Jack's beliefs on how the Anglo-Saxons will maintain their position in society which is that supposedly superior genes and a fighting spirit will carry them to victory against any and all racial others.

William Z. Ripley's influential text, The Races of Europe, argues that the Teutonic race holds the highest place in society. While Woodrow Wilson's The State merely asserted ideas of Anglo-Saxon supremacy, William Z. Ripley sought empirical evidence to prove it. Anglo-Saxons' Teutonic (or Germanic) roots were the supposed basis of racial supremacy. Ripley described three types of White European races, the Teutonic, the Alpine, and the Mediterranean. According to one of Ripley's charts, the Teutonic was described as having a "long head, a long face, very light hair, blue eyes, is of tall stature, and has a narrow or aquiline nose" (Ripley 121). The Alpine (or Celtic) is described as one with a "round head, broad face, light-chestnut hair, hazel-gray eyes, medium-stocky stature, and broad or heavy noses" (121). The third and final category, the Mediterranean, possess a "long head, a long face, dark brown or black hair, dark eyes, of medium to slender stature, and have rather broad noses" (121). Descriptions of physical characteristics were one component of Ripley's eugenic research. His research relied heavily upon exact measurements (length, width, mass, density, weight, etc.). 
Gathering these specific figures gave Ripley's study scientific legitimacy. Thus, these studies apparently proved the superiority that many already believed.

Many characters throughout London's oeuvre have characteristics of the Teutonic race. In The Valley of the Moon, Saxon and Billy are exemplars of this breed. Saxon is described in the following manner: "She was a flower of Anglo-Saxon stock, a rarity in the exceptional smallness and fineness of hand and foot and bone and grace of flesh and carriage - some throw-back across the face of time to the foraying Norman-French that had intermingled with the sturdy Saxon breed" (London 104-5). Here, Saxon's light complexion and hair represent the most desirable attributes of her race. London creates Saxon as a living being who embodies the history of the Anglo-Saxon race. Thus, Saxon's appearance exhibits all of the required Celtic and Nordic features, but also displays the Gallic and Germanic traces within this stock. For London, Saxon's makeup contains the premier traits of the superior European nations. She is superbly crafted. For Billy, she is a true thoroughbred and ideal for the propagation of their race. Her exquisite beauty is the result of the trace amounts of French within her. Saxon is thought to be the best that Europe has to offer.

However, Saxon's perceived fragility is coupled with that perpetual Anglo-Saxon tenacity. These traits conjure up Billy's desire to keep and protect her. For Billy, Saxon is beyond suitable. She is to be treasured. Yet, the pair's socioeconomic status does not allow Saxon and Billy to have the privileges of the Anglo-Saxon elite. Rather, they have been left behind. In the writings of various Progressives and proponents of eugenics, Billy and Saxon are example of combatants against race-suicide. Their privileges as 
Anglo-Saxons will be restored because of their tenacity and adherence to appropriate ethnic relationships.

\section{The "Other" Races in The Valley of the Moon}

As noted in Leonard's Illiberal Reformers, racial classification systems were plagued by subjectivity and complexity. For many of these Progressives, perception of race was often the product of an individual's choice. For example, the scholars of the era debated the classification of European Jewish people and Native Americans (and various other peoples). From the late 1880 s to the 1920 s there was a myriad of classification systems that all employed different methodologies, systems of measurement, and varying degrees of pseudo-science.

In terms of immigration, California was and remains a very attractive location in the United States. Therefore, California has always been a confluence of various cultures and races. The state's racial diversity is a fact that is not ignored by London. On the contrary, he maintains racist views and clings to notions of Anglo-Saxon superiority. His depiction of the Anglo-Saxon as a population in decline in California reflects anxieties over immigration and the fictions of eugenicists. In this way, London also depicts races and cultures that have long been demonized in American literature and society. Billy and Saxon encounter the Irish, the Chinese, Southern Europeans (Mediterranean, in Ripley's terminology), Mexicans, Native Americans, and Eastern Europeans (Both Jewish and Non-Jewish).

London's first mention of a non-Anglo Saxon ethnicity in the novel occurs in chapter one. Whilst working in the laundry, her friend Mary tells Saxon of the 
Bricklayers' gathering in Weasel Park. As a selling point, Mary lists the attractions of the event, “tugs-of-war, fat-man races, real Irish jiggin' an'... an' everything” (London 4). Aside from tests of strength and comedic displays, Mary chooses to mention Irish styles of dance as opposed to any other form of ethnic dance. Also, Mary views Irish dancing as an enticing prospect. From her statement, it would seem that the downtrodden Irish Americans are moving up in the American ethnic hierarchy. Mary and Saxon, two AngloSaxon women, recognize the Irish cultural contribution to this spectacle.

From the first chapter of the novel, it appears that London views the Irish in a relatively favorable light. According to Leonard, London's characterization of the Irish aligns with the prominent Bay Area nativist thought: "In San Francisco, however, where whites made the Chinese worker the paramount economic threat, Irish immigrants were promoted to 'American' so long as they joined in opposition to the Yellow Peril" (Leonard 135). However, London's compliments towards the Irish are backhanded. In comparing the first and second generation Irish Americans, London describes them as a healthy race of workmen, well-paid, and robustly fed. And with them, here and there, undisguised by their decent American clothing, smaller in bulk and stature, wizened not alone by age but by the pinch of lean years and early hardship, were grandfathers and mothers who had patently first seen the light of day on old Irish soil. Their faces showed content and pride as they limped along with this lusty progeny of theirs that had fed on better food. (London 8)

London's depiction of the elder Irishmen as small in stature and bulk aligns with the eugenic research of William Z. Ripley and other race scientists. The Celtic blood of the Irish was not believed to have enough of the Teutonic blood that allowed their 
contemporaries across the Irish Sea to flourish. While London's characterization of the pure Irishmen is negative, the Bricklayers who were born in the United States display traits similar to that of London's ideal Anglo-Saxon. In this manner, London depicts the otherness of the Irish Americans as diminishing through continued assimilation into the dominant culture. Better nutrition, employment, and interbreeding with those who have Teutonic genes allow the Irish Americans to better resemble London's ideal American.

Separate from London's characterization of the Irish Americans is Mary and Saxon's utilization of their racial conditioning to enter a state of self-segregation. Although these Irishmen have improved over time, they still represent the other. London underscores Mary and Saxon's behavior in their movement about the gathering:

Not with these did Mary and Saxon belong. They knew them not and had no acquaintances among them. It did not matter whether the festival were Irish, German, or Slavonian; whether the picnic was the Bricklayers', the Brewers', or the Butchers'. They the girls were of the dancing crowd that swelled by a certain constant percentage the gate receipts of all the picnics. (London 8)

Saxon, Mary, and other like-minded young women swarm to these events for the pleasure of dancing. Any European-American festival is suitable for young girls of all ethnicities. However, Saxon and Mary's innocent fun has more sinister implications. Unaccompanied women of the Anglo-Saxon race are supposed to have an innate awareness of their racial superiority. Unlike the German, Irish, or Slavonian (or any of those nationalities that are of Slavic origin), Anglo-Saxon women will not succumb to the wiles of lesser men. Therefore, they are free to gallivant about the festival. Their innate immunity will lead them to superior men. Yet, the presence of the inferior enables Mary and Saxon to 
identify those of a superior nature. This dancing about serves as prelude to their meeting with Bert Wanhope and Billy Roberts.

Upon meeting ideal Anglo-Saxon suitors, Mary and Saxon assume their proper role within society. Simultaneously, the festival begins its inevitable deterioration into chaos. From the very beginning, London speaks of negative Irish traits, which leads to this description of the festival: "The Celtic blood was up, and the Celtic faction spirit ran high" (London 21). Supposed inferior blood has a penchant for revelry, inebriation, and self-destruction. Although the Irish may resemble their Anglo-Saxon contemporaries, their behavior is inscribed upon their blood. The alcohol-fueled chaos originates in the contests of strength, diversity, and regionalism.

Witnessing a tug of war contest between Oaklanders and San Franciscans, a contest with both class and racial undertones, the festival begins its downward spiral. Billy utilizes his superior size and strength to intimidate and struggle with other patrons of the festival. Immediately following a footrace between a San Franciscan and an Oaklander, tensions escalate, which illustrates the alleged inherent nature of the Irish. Here, London illustrates the character of the Irishmen involved in the brawl: "Besides, for too many tedious hours had the Irish heroically suppressed themselves. Five thousands of them exploded into joyous battle. The women joined with them" (London 28). By showing how the festival became a melee, London revokes his sparse praise for the Irish people. In a backhanded compliment, the Irishmen held their tempers for much longer than they were expected to. The drunkenness and irascibility of the Irish festivalgoers aligned with public perception. 
The Irish propensity for drunken brawls is a common stereotype. Judging from The Valley of the Moon's historical context, these interactions underscore Celtic otherness. The Irish physically resemble the Anglo-Saxon and share similar genetic origins (as all humans do). However, this scene has the stench of race suicide about it. The brawl scene is reminiscent of Francis Amasa Walker's early argument that utilized race suicide theory. Thomas C. Leonard paraphrases Walker's description of the purported European contamination of American genetics: "Without immigration barriers, Walker warned, 'every foul and stagnant pool' of Europe would soon be 'decanted upon our shores"' (Leonard 144). For London and the Progressives, this decanting of genes needed to be halted at all costs.

London's fictional depiction of Irish mischief reflects the agenda of various Progressive intellectuals. Irish blood and that of other Northern Europeans (Germans, Swedes, Norwegians, etc.) was simply not good enough for the continuation of the Anglo-Saxon race. The Anglo-Saxon could not thrive in the space that lesser races occupied. While the Irish may improve by the decanting of their genes, Anglo-Saxon decline was thought to be inevitable. Thus, London positions four Anglo-Saxons as the great hope against the surging numbers of immigrants.

Together with their surnames, heritage, and racial identities, Billy and Saxon's manners of employment are also symbolic. As a laundress, Saxon literally maintains the purity of the garments that she washes. As a teamster, Billy works with horses and has that inborn Anglo-Saxon affinity for animals, nature, and difficult physical labor. In both cases, these two vocations are under threat. Ethnic minorities (the Chinese, for example) represent a sizable portion of the workforce within many laundries while teamsters are 
steadily losing their role to the automobile and the modernization of transportation. Throughout The Valley of the Moon, the Chinese are also used as markers against which to promote the alleged superiority of the Anglo-Saxon race.

As with the Irish, the Chinese are characterized as single-faceted workers. According to Thomas Leonard, Edward A. Ross said, "the Coolie "cannot outdo the American,' but 'he can underlive him"' (Leonard 134). Therefore, Progressives believed that Chinese immigrants were best suited for unskilled labor, gambling, and opium consumption. Billy utilizes these stereotypes to confirm his race's position in society: "We ain't Chinks. We're White folks. Does a Chink ever want to ride a horse, hell-bent for election an' havin' a good time of it? Did you ever see a Chink out swimmin' through the breakers at Carmel? —or boxin', wrestlin', runnin' an' jumpin' for the sport of it?" (London 341). Channeling the rhetoric that Said studies in Orientalism, Billy uses the other to define himself.

Throughout his statement, Billy uses examples to show the difference between "white folks" and the Chinese. He believes that the Chinese are unable to amuse themselves. Supposedly, for a Chinese person, riding a horse is always a chore. For Billy, riding a horse is both a means of employment and a natural source of recreation. London's Anglo-Saxon, much like the stereotype of the American Indian, is closer in proximity to man's more primitive impulses. Yet, London's Anglo-Saxon also possesses a superior sense of rationality.

The Chinese are also cast as others to depict their apparent lack of aptitude for achieving great physical feats. Billy believes that the waves at Carmel would engulf lesser races. He also suggests that viewing the Chinese behave in an Anglo-Saxon 
manner would be ridiculous. For Billy and Saxon, this behavior would amount to an absurdity. Also present here is the idea that the Anglo-Saxon is prone to challenging himself for the sheer sport of it. Billy implies that Chinese people would only try to complete these tasks if their survival depended on it.

However, to Billy and Saxon's dismay, the Chinese are very successful in Northern California. During a conversation on a train with a Jewish man named Gunston, Billy asserts that the white man is capable of the same tasks as any Chinese man. Gunston entertains Billy's notion and then discusses the Chinese agricultural prowess at length: “"That sounds all right,' Gunston replied. 'The only objection is that the white man doesn't. The Chink is busy all the time, and he keeps the ground just as busy. He has organization, system. Who ever heard of white farmers keeping books? The Chink does"” (London 340). In Gunston's opinion, the Chinese farmers are prosperous because they do not delegate their work to third parties. The Chinese farmer completes all the tasks on his own and he has not become prone to idleness. Gunston explains that the white farmer has grown comfortable in his ways. Gone are the self-reliant Anglo-Saxon settlers of the west. While Billy places the bulk of the blame on other races coming to America, he is unaware that the Anglo-Saxons were no longer the bulk of the working class.

Billy and Gunston's perspectives reflect those examined by Michael H. Hunt in Ideology and U.S. Foreign Policy. Hunt explains the argument against Chinese immigration (and other Asian nationalities) at the turn of the twentieth century: "The interests of free labor should be protected from 'Asiatic competition' and white morals defended against a corrupting race" (Hunt 77). From Gunston's speech in The Valley of the Moon, London would have readers believe that the Chinese and all other ethnicities 
maintained a stranglehold over California's resources. Therefore, Billy and Saxon's agricultural ambitions are the means with which they can retake the land that was conquered by their forebears.

Of all the threatening races in the novel, London seems most amiable towards the Irish and Chinese. By the end of the novel, Billy and Saxon use their Anglo-Saxon logic and recruit Chinese workers for their land in the Sonoma Valley. The Chinese workers serve as an invaluable resource and aide in the creation of Saxon and Billy's budding empire. While never quite equal to the Anglo-Saxons, and in line with the thinking of race scientists of the era, London positions the Chinese at a middle level of the social ladder. In California, there appears to be enough room for all of the races. However, London's social structure forever champions the Anglo-Saxon.

Aside from the Chinese and the Irish, there remain two other menacing ethnicities within The Valley of the Moon, Southern and Eastern Europeans. The Southern Europeans are composed mainly of Italians and Portuguese. The Eastern European contingent is composed of Croatians and the various ethnic groups from the Balkans. Both of these groups belong to Ripley's Mediterranean (Portuguese and Southern Italians) and Alpine subgroups of the Caucasians. However, as seen in Ripley's work (and the work of many other race scientists), there was an immense overlap between ethnicities and almost no consensus among scholars of the era. Despite race scientists' lack of credibility, it does not lessen the animosity many Americans once held towards these ethnicities.

Of all the ethnic groups described within The Valley of the Moon none are cast as insidious as the Portuguese and Eastern Europeans. They are thought of as unclean, 
emotional, suitable only for unskilled labor, and prone to having large families. Saxon and Billy view these groups' numbers as an affront to the sanctity of Anglo-Saxon California. Throughout their travels, the Portuguese are the most encountered ethnic group. At one point, Billy and Saxon encounter real "Americans" and begin to discuss the current state of labor in California. One of these workmen, a lineman, tells Billy and Saxon of the successful Portuguese men in the area. This fact causes Saxon to question the state of American society: “'But how do they do it?' Saxon continued to demand. 'We've never been ashamed to work. We've worked hard all our lives. I can out-work any Portuguese woman ever born. And I've done it too"' (London 249). Akin to Billy's reaction to Gunston's explanation of the Chinese, Saxon tries to counteract the Portuguese presence in her country.

Following Saxon's repudiation of the Portuguese immigrants, the lineman continues to explain the dire situation of the American worker. In his perspective, Americans are not equipped with the appropriate level of knowledge, and somehow these Southern Europeans are more attuned to the land. The lineman claims: "We ain't got the sabe, or the knack, or something or other... Why, back in town there, ther's single acres that earns more than fifty of ours in the old days. The Porchugeeze is natural born farmers, that's all, an' we don't know nothin' about farmin' and never did"' (London 250). Here, London presents a character that expresses doubt in Anglo-Saxon superiority. However, Billy and Saxon take a hard stance against this type of rhetoric. It is their belief that the Portuguese are "winning" only because they are trying. If the Anglo-Saxons were so inclined, they would also thrive. Yet, their superior position in society spreads them thin. This idea is similar to the theme of Rudyard Kipling's 1899 
poem, “The White Man's Burden,” which asserts that white men hold the highest position on the planet. The poem serves as a justification for Anglo-Saxons taking care of the earth and its inhabitants. The fear present in Gunston and Billy's minds is that there is the possibility that there may come a time where the world no longer needs its supposed Anglo-Saxon caretakers.

In addition to the Southern Europeans, there is another threat rising in the countryside. Eastern Europeans, mostly of Balkan nationalities, also possess an innate affinity for the land. Unlike the Portuguese and Italians, these Dalmatians (one of the antiquated demonyms for Croatians favored by London) are a hardy and capable people. As California became a haven for Croatian immigrants, many were quick to notice their difference. Despite Croatia's (and the rest of the Balkans') proximity to other Southern European nations, these people were marked as different. Many race scientists believed that Southeastern Europeans were a different variety altogether. The subtitle for the Eastern European section of The Races of Europe is titled "Greek, Turk, and Slav" (Ripley 401), suggesting that Ripley relied on the ethnic makeup and geography of the Ottoman Empire for these racial designations.

For London, the Eastern Europeans were another antagonist for Saxon and Billy. With the Chinese, Irish, Mexicans, Southern Europeans all diminishing the AngloSaxon's domination, the Slavic Eastern Europeans were just another body on the dog pile. Billy's employer, Benson, explains the alleged nature of the Slavic peoples: "These Adriatic Slavs are longheaded in business. Not only can they grow apples, but they can sell apples. No market? What does it matter? Make a market" (London 292-3). For Benson, the Slavs are very impressive in their self-reliance. They harbor traits that have 
faded from the Anglo-Saxon. Besides self-reliance, there are two other ideas at play in Benson's statement. First, there is the idea that the Slavs are "longheaded." While it is a turn of a phrase that denotes an aptitude for mercantilism, it also parallels the cranial research of William Z. Ripley who remarked, "these Illyrians tend to be among the broadest-headed people known" (Ripley 413). Although London mentions length and Ripley focuses on width, the purported largeness of Balkan peoples' heads shows that London is relatively consistent with the "research" of Ripley. The second idea here is that the Slavs have an aptitude for creating their own market for their goods. This shrewdness in business also may hint at a portion of their heritage that is not as apparent in the Southern Europeans.

Shrewdness in business is a trait that William Z. Ripley (among others) assigned to the denizens of the Adriatic coast and to Jewish people irrespective of nationality. Within The Valley of the Moon, these vicious assumptions about Eastern Europeans and adherents of Judaism illuminate a potential Anglo-Saxon flaw. After listening to Benson's explanation, Saxon and Billy consider that the Anglo-Saxon may be inept in certain arenas. Unlike Eastern Europeans of all religious denominations, Billy and Saxon believe that the Anglo-Saxons' greatest strength exists in their aptitude for conquest and farming. For Billy and Saxon, the Eastern Europeans (and all other mentioned ethnicities) of the novel were not present for the Anglo-Saxons' initial conquest of the country and therefore have not earned the right to succeed in the United States. Billy and Saxon employ the faulty logic that the United States belongs to them because their ancestors were the original colonizers and "righteously" toppled legions of Native American tribes. 
This aptitude for commerce illuminates the Progressive ideal that foreign elements undercut Anglo-Saxon development. As Anglo-Saxons were regarded as racial superiors, their skills in combat dulled their mercantile prowess. Eastern Europeans did not help settle the American West. Therefore, other ethnicities exploit the reeling AngloSaxon. Casting them as new victims of immigration, London's The Valley of the Moon ultimately contains a doubtful tone when it comes to Anglo-Saxons. During Billy and Saxon's exchange with Benson, the latter laments that the days of the Anglo-Saxon are over. Benson sorrowfully claims: “'Oh it's a great country,' Benson was continuing. 'But we're not a great people. Kipling is right. We're crowded out and sitting on the stoop. And the worst of it is there's no reason we shouldn't know better"' (London 293). Benson refers to Kipling's “The White Man's Burden” to underline the uncertainty felt by Anglo-Saxons. Benson also misreads Kipling's justification for the continuation of imperialism as an elegy for Anglo-Saxon dominance. However, Billy and Saxon regard Benson's doubt of the Anglo-Saxon as ludicrous. As ideal Anglo-Saxons, Billy and Saxon are not swayed by the sentiments of a disillusioned landowner. For London, true Anglo-Saxons must emulate Billy and Saxon and recolonize the rural landscape.

As London depicts the Eastern and Southern Europeans as usurpers of California, he also identifies a potential threat from Mexican-Americans. In the early twentieth century, Hispanics occupied an ambiguous space on the racial hierarchy. According to William Z. Ripley's The Races of Europes, "In the Americas, we find the color quite variable, ranging all the way from the dark Peruvians and the Mexicans to the aborigines north of the United States" (Ripley 60). Due to their ambiguity, Mexicans are not nearly as threatening as the Italians, Portuguese, or Eastern Europeans. Rather, Mexicans are 
trivial. In one exchange between Mary and Saxon, Saxon comments on this triviality: “'You know that little, wrinkly Mexican that sells wire puzzles?' Saxon queried 'Well, God somehow always reminds me of him.' Mary laughed outright" (London 11). Here, London uses this dichotomy to comment upon two aspects of society. The first aspect of this comment is that Mexicans are frivolous contributors to society. Second, Mary's reaction demonstrates that Saxon's idea that a Mexican can help prove the existence of God is hilarious. For Mary, the notion of God's existence is questionable. Also, as an Anglo-Saxon, Mary must believe that God resembles her. Thinking otherwise would dismantle the constructed racial hierarchy of American society.

In The Valley of the Moon, there are no Mexican characters other than those who appear in London's descriptions of the scenery or in characters' conversations. However, early in the novel, Billy and Saxon take up residence in Oakland. Here, Saxon encounters Mercedes and questions her ethnic background:

"You are Spanish?" Saxon ventured. "No, and yes, and neither, and more. My father was Irish, my mother Peruvian Spanish. 'Tis after her I took, in color and looks. In other ways after my father, the blue-eyed Celt with the fairy song on his tongue and the restless feet that stole the rest of him away to far-wandering. And the feet of him that lent me have led me away on as wide far roads as ever his led him." (London 110)

Without overtly classifying her, London uses Mercedes to capture the diverse makeup of many Hispanics. For Saxon, Mercedes' hybridity is off-putting. With dark features and wanderlust, Mercedes is more cultured than Saxon but also more decadent. In their 
encounters, Mercedes often tells Saxon of faraway lands and their riches. Mercedes is wealthy, indolent, and self-indulgent. She lives off the hard work of those around her.

Mercedes' hybridity is akin to the eugenic theory that when races mix, their strengths are diluted. Thus, Mercedes is a mélange of the worst of the Celtic, Iberian, and Indigenous genes. Her genetic makeup hinders her sense of morality. She subsists only on her cunning. For London, this is not a marker of intellect. Rather, Mercedes' traits display a disintegration of racial integrity. These characteristics cause Billy to remark upon Mercedes and her husband: "Old Higgins an' her- a funny bunch, the two of them. The people's scared of her- some of 'em. The Dagoes an' some of the old Irish dames thinks she's a witch" (London 109). While ethnicities lower on London's hierarchy may be prone to superstition, Billy's alleged inherent Anglo-Saxon intuition allow him to see through the anxieties of the others. While she is not to be trusted, Billy deems Mercedes to be harmless. Utilizing London's virulent Anglo-Saxonism, those who threaten the lesser races cannot be on an equal footing with these true Americans.

Throughout the breadth of American literature, the mixed race character is often regarded as menacing (Tom Sawyer's nemesis Injun Joe, for an earlier example). Mercedes speaks to Saxon of how to manipulate men to gain riches: "Listen, my dear. I shall tell you about the world of men. Do not be stupid like all your people who think me foolish and a witch with the evil eye... A witch I have been, 'tis true, but my witchery was with men...I shall tell you of women's ways with men, and of men's ways with women" (London 113). In this remark, Mercedes reveals the lesser angels of her nature. She tries to undermine Saxon's status as a pure Anglo-Saxon woman. However, Saxon is 
not enticed by Mercedes' sermon. Rather, Saxon relies upon her innate ingenuity and absorbs Mercedes' useful information while ignoring her more unsavory ideas.

Mercedes' presence within the novel is to cement London's position on the superiority of the Anglo-Saxon. Of all the ethnicities present in The Valley of the Moon, none can drive a wedge between Billy and Saxon. London's Anglo-Saxon is able to face hardship from nature and society, and competition from other races. It is his or her ostensible superiority that allows for the re-colonization of California. Therefore, London's Anglo-Saxon is defined by the others and has an almost divine mandate over the United States of America.

The Valley of the Moon offers a unique look at the Anglo-Saxon sentiments of the early twentieth century. The novel's extensive exploration of the California landscape and demography reveals London's thoughts on the effects of immigration on the AngloSaxon population of California. London, much like William Z. Ripley, is actively participating in constructing an American racial hierarchy. Older immigrant groups (the Irish and Chinese) are cast as undeserving and ill bred, while newer batches of immigrants (Southern and Eastern Europeans) are formidable enemies to the prosperity of the Anglo-Saxon race. Ripley's hierarchy signals an arbitrary system of hatred that is distinctly American. London channels anxieties about racial integration and the failure of political systems through Saxon and Billy's quest about the California landscape.

Ultimately, London seeks to reeducate the Anglo-Saxon readers who are ignorant of their heritage. If these old ways are forgotten, the Anglo-Saxon Übermensch lose their power. The Valley of the Moon serves as a beacon that guides wanderers back to the old ways. As a guidebook, it appears that this novel yearns for a return to a Pre-industrial society. 
With increasing modernization and a growing population, Oakland (along other urban centers) is regarded as a cesspool of devolution. In London's novel, there is disillusionment with urban society and racial heterogeneity that speaks to the anxieties of Progressive intellectuals. Therefore, Billy and Saxon's burgeoning agricultural business aligns with the Progressive ideal that the federal government should employ socialistic programs to aide its Anglo-Saxon members. London asserts that a return to nature will restore the Anglo-Saxon and that their renewed vigor would be a panacea for societal conflicts.

Tied to the Social Gospel of Josiah Strong, Progressives believed that advancing the Anglo-Saxon working class was a humanistic endeavor. Ostensibly, aiding the AngloSaxon component of society was for the betterment of humankind. Altogether, London's The Valley of the Moon is a hodge-podge of various political ideologies. London echoes Progressive desires for social welfare programs that benefit Anglo-Saxons. The final component of the novel utilizes the eugenics of Ripley and others in an attempt to legitimize Anglo-Saxon superiority and ownership of the United States. Utilizing faulty logic, London and the Progressives believed that government agencies and innate racial characteristics would allow for a resurgence of the Anglo-Saxon. These vile and contradictory ideals represent and epitomize a dangerous period in American history. While great strides were made regarding the rights of women and American workers, the complexities of these racial hierarchies would sow the seeds of chaos for generations. 


\section{CONCLUSION: NORRIS AND LONDON}

Anglo-Saxonism's stranglehold over these two authors dictated their worldviews.

Frank Norris and Jack London's brutal tales exemplify the dominant ideology of the era. The alleged perils of racial diversity are catalysts in the evolution of Anglo-Saxonism, which heavily influences the contents of these novels. Jack London casts Billy and Saxon Roberts as the champions against a raging tide of immigration and miscegenation. In London's view, warrior blood flows in his characters' veins. The pair embodies the author's conception of quintessential Americans. In an offering of hope, The Valley of the Moon ends as Saxon announces her pregnancy in a sylvan scene. A doe and her fawn emerge from the wood as Saxon and Billy survey their land. This doe stands for motherhood in the animal kingdom and the child in Saxon's womb signifies London's hope for the Anglo-Saxons. Despite all of their anguish, Saxon and Billy serve as a glimmer of hope for the continuation of the Anglo-Saxon race. London's protagonists emerge victorious against the odds of thriving in chaotic Oakland and its environs.

Norris's approach to McTeague differs from The Valley of the Moon in that it paints an even bleaker portrait of urban life. San Francisco's ethnic makeup demonstrates an unnerving prospect for an idealized Anglo-Saxon. Norris's uses an extensive account of vice, murder, sexual violence, greed, and brutality to characterize San Francisco's immigrant community. By bestowing these attributes upon recent arrivals (either immigrants or descendants of non-Anglo-Saxons), Norris can blame the city's inhospitable nature on its "other" residents. McTeague's final struggles in the unforgiving sands of Death Valley reflect Norris's idea that the "other" is incompatible with the “true" American. In that final scene with Marcus and McTeague, Norris displays the 
struggle between a man of Celtic (Scots-Irish) and Teutonic (German) descent. Regardless of the landscape, the pairs' ethnicities and physical conflict highlights Norris's idea that groups of immigrants are responsible for all discord in American society.

Likewise in both novels, the urban dweller lives in a greater state of competition. The life in cities is based on scarcity, which causes London to idealize rural municipalities as potential bastions of Anglo-Saxons. The idea of a return to an agrarian lifestyle romanticizes an American past that never truly existed. Saxon and Billy's return to this way of life is a figurative seed that suggests an Anglo-Saxon resurgence. It is as if London encourages his Anglo-Saxon readers to reclaim their heritage by populating and retaking the Californian landscape.

These two novels reflect Progressive values by reassembling their Anglo-Saxon centrism, their view of working class struggles, and their desire for more effective administration. The Valley of the Moon and McTeague each contain vile depictions of immigrants, ethnic minorities, and females. However, the pervasive presence of the that dominant ideology was undeniable at the time. For Progressives, and these authors, change can be good if it enables the survival of their idealized Anglo-Saxons. Altogether, these insidious depictions of race resemble both "scientific depictions" and political discourse. This glorification of the Anglo-Saxon helped to shape the reality of the early twentieth century and in understanding it, readers can better address its fraught legacy. 


\section{REFERENCES}

Althusser, Louis. "Ideology and Ideological State Apparatuses: (Notes towards an Investigation)." Lenin and Philosophy and Other Essays. Ed. Ben Brewster. New York: New York University Press, 2001, pp. 85-126. JStor. Web.

Delgado, Richard, et al. Critical White Studies: Looking Behind the Mirror. Philadelphia: Temple University Press, 1997. Print.

Foucault, Michel. Discipline and Punish: The Birth of The Prison. New York: Pantheon, 1977. Print.

Galton, Francis. Hereditary Genius: An Inquiry into Its Laws and Consequences. London: Macmillan, 1892. HathiTrust. Web.

Gair, Christopher. "“The Way Our People Came: Citizenship, Capitalism and Racial Difference in 'The Valley of the Moon'". Studies in the Novel 25.4 (1993): 418435. JSTOR. Web.

Gyory, Andrew. Closing the Gate: Race, Politics, and the Chinese Exclusion Act. Chapel Hill: University of North Carolina, 1998. Print.

Horsman, Reginald. Race and Manifest Destiny: The Origins of American Racial AngloSaxonism. Cambridge, Mass: Harvard University Press, 1981. Print.

Hunt, Michael H. Ideology and U.S. Foreign Folicy. New Haven, CT: Yale University Press, 1987. Print.

Ignatiev, Noel. How the Irish Became White. New York: Routledge, 1995. Print.

Kershaw, Alex. Jack London: A Life. London: Harper Collins, 1997. Print.

Kipling, Rudyard. Rudyard Kipling. Ed. Daniel Karlin. Oxford: Oxford University Press, 1999. Print.

LaFeber, Walter. The New Empire: An Interpretation of American Expansion, 18601898. Ithaca, NY: Cornell University Press, 1963. Print.

London, Jack. To Build a Fire and Other Stories. Ed. Donald Pizer. New York: Bantam Books, 1988. Print.

London, Jack. The Game. Lincoln: University of Nebraska Press, 2001. Print.

London, Jack. The Valley of the Moon. Berkeley: University of California Press, 1999. Print. 
Marx, Karl, and Friedrich Engels. Wage-Labor and Capital. Vancouver: The Whitehead Estate, 1919. HathiTrust. Web.

Michaels, Walter Benn. Our America: Nativism, Modernism, and Pluralism. Durham: Duke University Press, 1995. Print.

McElrath, Joseph R. Frank Norris Revisited. New York: Twayne, 1992. Print.

Nisetech, Rebecca. "The Nature Of The Beast: Scientific Theories Of Race and Sexuality In McTeague." Studies In American Naturalism 4.1 (2009): 1-21. Academic Search Complete. Web.

"nostalgia, n." OED Online. Oxford University Press, December 2016. Web. 3 February 2017.

Norris, Frank. McTeague: A Story of San Francisco. Ed. Donald Pizer. New York: Norton, 1977. Print.

Pizer, Donald. "Realism and Naturalism: The Problem of Definition." Introduction. The Cambridge Companion to American Realism and Naturalism. Cambridge: Cambridge University Press, 1995. Print.

Ripley, William Z. The Races of Europe: A Sociological Study. London: Kegan Paul, Trench Trübner, 1900. Print.

Roediger, David R. The Wages of Whiteness: Race and The Making of The American Working Class. London: Verso, 1991. Print.

Said, Edward. Orientalism. $25^{\text {th }}$ Anniversary ed. New York: Vintage, 1988. Print.

Strong, Josiah. Our Country: Its Possible Future and Its Present Crisis. New York: Baker \& Tylor Co., 1885. HathiTrust. Web.

"Teague | Taig, n." OED Online. Oxford University Press, December 2016. Web. 2 March 2017.

Weinberger, Bernhard W. An Introduction to the History of Dentistry. St. Louis: C.V. Mosby Co, 1948. HathiTrust. Web.

Wilson, Woodrow. The State: Elements of Historical and Practical Politics. Boston: D.C. Heath \& Co. 1889. Google Books. Web. 